\author{
Luke E. Stoeckel ${ }^{1}$, Zoe Arvanitakis², Sam Gandy (i]3, Dana Small4, C. Ronald Kahn5, \\ Alvaro Pascual-Leone ${ }^{6}$, Aaron Pawlyk1 ${ }^{1}$, Robert Sherwin"4, Philip Smith1 \\ ${ }^{1}$ National Institute of Diabetes and Digestive and Kidney Diseases, National Institutes of Health, Bethesda, MD, USA \\ ${ }^{2}$ Rush Alzheimer's Disease Center, Rush University Medical Center, Chicago, IL, USA \\ ${ }^{3}$ Icahn School of Medicine and James J. Peters VAMC, New York, NY, USA \\ ${ }^{4}$ Yale University School of Medicine, New Haven, CT, USA \\ 5Joslin Diabetes Center, Harvard Medical School, Boston, MA, USA \\ ${ }^{6}$ Berenson-Allen Center for Noninvasive Brain Stimulation and Division for Cognitive Neurology, Beth Israel Deaconess Medical \\ Center, Harvard Medical School, Boston, MA, USA
}

V1 First published: 15 Mar 2016, 5:353
https://doi.org/10.12688/f1000research.8300.1

Latest published: 02 Jun 2016, 5:353

https://doi.org/10.12688/f1000research.8300.2

\begin{abstract}
Scientific evidence has established several links between metabolic and neurocognitive dysfunction, and epidemiologic evidence has revealed an increased risk of Alzheimer's disease and vascular dementia in patients with diabetes. In July 2015, the National Institute of Diabetes, Digestive, and Kidney Diseases gathered experts from multiple clinical and scientific disciplines, in a workshop entitled "The Intersection of Metabolic and Neurocognitive Dysfunction", to clarify the state-of-the-science on the mechanisms linking metabolic dysfunction, and insulin resistance and diabetes in particular, to neurocognitive impairment and dementia. This perspective is intended to serve as a summary of the opinions expressed at this meeting, which focused on identifying gaps and opportunities to advance research in this emerging area with important public health relevance.
\end{abstract}

Keywords

Diabetes, insulin resistance, obesity , cognition, cognitive impairment, Alzheimer's disease, vascular dementia, mechanism

Open Peer Review
Approval Status
version 1
15 Mar 2016
(revision)
1. Steven W Ban 2016
Medical Sciences, Little Rock, USA
University of Arkansas for Medical Sciences,
Little Rock, USA
Central Arkansas Veterans Healthcare
System, Little Rock, USA
2. Mahmoud Reza Azarpazhooh, University of
Western Ontario, London, Cana...............................


Mashhad University of Medical Sciences,

Mashhad, Iran

Vladimir Hachinski, University of Western

Ontario, London, Canada

Any reports and responses or comments on the article can be found at the end of the article.

Corresponding author: Luke E. Stoeckel (luke.stoeckel@nih.gov)

Competing interests: No competing interests were disclosed.

Grant information: The following National Institutes of Health grant funding supported this work: R01 NS084965 (Z.A.); U01AG046170 (S.G.; Eric Schadt); R01 DK 085579 (D.S.); P50 AG005138 (S.G.; Mary Sano, PI); R01 CA 180030 (D.S.); R01 NS075685 (S.G.); R01 DC 006706 (D.S.);P30 AG10161 (Z.A.; David A. Bennett, PI); R01 AG 040039 (Z.A.); R21 NS082870 (A.P.L.).

Copyright: @ 2016 Stoeckel LE et al. This is an open access article distributed under the terms of the Creative Commons Attribution License, which permits unrestricted use, distribution, and reproduction in any medium, provided the original work is properly cited. The author(s) is/are employees of the US Government and therefore domestic copyright protection in USA does not apply to this work. The work may be protected under the copyright laws of other jurisdictions when used in those jurisdictions.

How to cite this article: Stoeckel LE, Arvanitakis Z, Gandy S et al. "White Paper" meeting summary and catalyst for future inquiry: Complex mechanisms linking neurocognitive dysfunction to insulin resistance and other metabolic dysfunction [version 1; peer review: 1 approved, 1 approved with reservations] F1000Research 2016, 5:353 https://doi.org/10.12688/f1000research.8300.1

First published: 15 Mar 2016, 5:353 https://doi.org/10.12688/f1000research.8300.1 


\section{Background}

Emerging data have established links between systemic metabolic dysfunction, such as diabetes, and neurocognitive impairment, including dementia. The current epidemic of dementia is driven, at least in part, by the concurrent epidemics of obesity, insulin resistance, diabetes, and metabolic syndrome. Early research sought to elucidate the cause(s) for the apparent role of metabolic dysfunction in the increased prevalence of neurocognitive dysfunction and dementia, tentatively attributed to vascular contributions to cognitive impairment and dementia (VCID), and Alzheimer's disease $(\mathrm{AD})$.

More recent research has revealed that the relationships linking metabolism and brain dysfunction are bidirectional. On the one hand, diabetes increases risk of dementia by about two-fold, while on the other hand, the development of neurocognitive disorders has been linked to an increased risk of metabolic disease (Biessels et al., 2014). While the relationships linking metabolism and brain dysfunction in humans are more complex and more difficult to study in isolation, mouse models of isolated cerebral amyloidosis and cerebral amyloid angiopathy have been discovered to have peripheral insulin resistance (Ruiz et al., 2016).

Genetic, epigenetic, environmental, and other mechanisms (likely in combination) are being implicated as underpinning these relationships and, in some cases, with behavior acting as a disease modifier. Of particular interest, both peripheral insulin resistance (the central pathophysiologic feature of type 2 diabetes) and "brain insulin resistance" (a much-discussed but poorly characterized entity) have been suggested to play important roles in neurocognitive dysfunction and dementia. Insulin resistance and the associated metabolic dysregulation can be driven by high-fat ("Western") diet, physical inactivity, and obesity, and have deleterious effects on neurocognition (Ishii \& Iadecola, 2015a).

Because the pathophysiological processes that lead to metabolic and neurocognitive dysfunction precede the development of clinical syndromes by years, early intervention and preventive measures are possible and an area of intense study (Norton et al., 2014). Indeed, AD neuropathology is detectable more than 10 years before the onset of the first clinical symptoms (Bateman et al., 2012) and pre-diabetes also precedes diabetes by years in most cases. There is now a focus on biomarkers and intervention research at pre-disease states, as there may be a higher chance that diseases are modifiable at this stage and prevention may be attainable (Sperling et al., 2015).

Confounding the picture is evidence that diabetes worsens VCID and, in turn, that VCID increase the likelihood of developing AD pathology. Nonetheless, diabetes and dementia are complex diseases, with heterogeneous risk factors, underlying mechanisms, and clinical expressions, often with different contributing co-morbidities.

In this era of precision medicine, it is imperative that we identify the various metabolic-neurocognitive phenotypes in order to understand the mechanisms that drive these diseases so that we can develop targeted therapeutic strategies to successfully manage and, hopefully, prevent these complex, multifactorial diseases.

In July 2015, the National Institute of Diabetes and Digestive and Kidney Diseases (NIDDK) at the National Institutes of Health (NIH) gathered a group of cross-disciplinary scientific experts in Bethesda, MD for purposes of:

(1) Reviewing the state-of-the-science;

(2) Identifying key knowledge gaps and critical unanswered questions; and

(3) Developing ideas for future directions to advance investigation at the intersection of metabolic and neurocognitive dysfunction.

The meeting focused on clarifying leading candidate mechanisms that may explain relationships between metabolic and neurocognitive dysfunction, with a special emphasis on the bidirectional relationships between diabetes and/or insulin resistance (either peripheral, central, or both) and cognitive impairment and $\mathrm{AD}$ and/or VCID. Although there has been increased attention to the neurodegenerative and/or vascular contributions to cognitive impairment and dementia (Snyder et al., 2015), it is important to consider the contributions of mechanisms that may not fall into either category as well as mechanisms that span multiple categories.

In this White Paper, we have attempted to survey and summarize the opinions among the experts in attendance with regard to the most likely mechanisms to investigate in order to improve our understanding of diseases and disorders at the interface of metabolism and cognition; in other words, to address the questions of "what do we know now?" and "what directions should be pursued in order to advance that knowledge?". In so doing, we aim (a) to improve public health at the level of community medical care that considers patients within the context of their behaviors and environment; and (b) to inform public policy that would be required for a major effort toward prevention of these common co-morbid conditions of high societal burden.

\section{Summary of current knowledge \\ Diabetes and neurocognitive dysfunction (including dementia)}

The high prevalence of type 2 diabetes $(\sim 26 \%)$ and dementia $(\sim 11 \%)$ in individuals $>65$ years old, and the increased relative risk of all-cause dementia ( $\sim 2$ to $\sim 2.5$-fold) conferred by type 2 diabetes make understanding this connection a major public health imperative. Even individuals with type 2 diabetes without dementia have subtle impairment in performance (a third of a standard deviation, compared to individuals without diabetes) in a range of cognitive functions, including learning and memory, processing speed, and executive function across the lifespan (Biessels et al., 2014). These decrements in cognitive function are accompanied by structural and functional brain changes, with one estimate 
attributing five years of brain aging (based on volumetric magnetic resonance imaging, MRI) to diabetes relative to chronological age and estimates in those without diabetes (Franke et al., 2013). The most common neuroimaging findings include modest white and gray matter atrophy (most pronounced in the temporal and frontal cortices), cerebral small vessel disease, and disrupted structural and functional connectivity (Biessels \& Reagan, 2015). Of relevance to understanding pathophysiologic mechanisms linking diabetes and neurocognition is that some of these brain changes may be observed prior to the development of diabetes (Brundel et al., 2014; Convit et al., 2003).

The neurocognitive profile of diabetes shares features with aspects of cerebrovascular disease and AD. However, it is still unclear if the relationship between diabetes and neurocognitive dysfunction and dementia is due to classic AD pathology, vascular processes such as infarcts or vessel pathology, other pathologies less closely related to $\mathrm{AD}$ or vascular disease (e.g., impaired brain insulin signaling), or some combination of these. Some have proposed that "all-cause" dementia be employed in order to avoid the implication that we can classify etiologies accurately based on current knowledge. Understanding the mechanism(s) that explain the neurocognitive complications of diabetes and other metabolic disease will be important if we are going to be successful in developing therapeutic targets and approaches to mitigate the effects of metabolic disease on the brain and cognitive function. This is especially the case if metabolic disease impacts the brain in ways that differ from its effects on other end organs impacted by diabetes and other metabolic disease.

The CNS pathology associated with metabolic disease has largely been characterized as a cognitive disorder with most of the research focused on brain regions and networks that support higher-order cognitive functions. Research on the central regulation of energy balance and peripheral metabolism, on the other hand, has almost exclusively focused on the hypothalamus and brainstem, brain regions and networks whose contributions to higher-order cognitive functions may not have been fully defined. The recent appreciation of the bidirectional relationship between diabetes and neurocognitive dysfunction/dementia presents an opportunity to combine efforts and resources to tackle both of these complex and related problems together. Cerebral amyloidosis can precede clinical cognitive decline for up to 30 years, and during this early phase may occur in limited regions of the brain. Therefore, it is plausible that $\mathrm{AD}$ pathology (amyloid-beta or $\mathrm{A} \beta$, tauopathy) may be present in the hypothalamus prior to the onset of cognitive symptoms, and that this hypothalamic pathology could disrupt homeostatic functions such as energy balance and peripheral metabolism prior to the onset of detectable cognitive dysfunction (Ishii \& Iadecola, 2015b).

\section{Mechanisms linking diabetes to dementia}

While diabetes is known to increase risk for dementia, the underlying mechanisms linking these conditions is less clear. Undoubtedly, given the well-established micro- and macro-vascular complications of diabetes, the least disputed mechanism of brain injury involves cerebrovascular disease. Indeed, it is now wellestablished that diabetes, and elevation in the most frequently used biomarker of diabetes (hemoglobin A1c), increases the risk of stroke, and that stroke in turn, increases the risk of cognitive impairment and dementia, including vascular dementia (Abbott et al., 1987; Banerjee et al., 2012; Gorelick et al., 2011; Ivan et al., 2004; Li et al., 2012; Ramirez et al., 2015). Aside from brain infarction, the central pathologic feature of stroke (Arvanitakis et al., 2006a), other vascular and related processes in the brain plausibly play a pathophysiologic role in relating diabetes to dementia, including white matter disease, breakdown of the blood brain barrier, inflammation, and others (Hsu et al., 2012; Shimizu et al., 2013). Also, co-morbid conditions to diabetes, such as hypertension, hypercholesterolemia, and obesity, and complications of diabetes such as myocardial infarction, can lead to cerebrovascular disease and dementia, either alone or in concert with one another (Yaffe, 2007). The published literature as a whole suggests about a two-fold increased risk of stroke in individuals with diabetes, pointing to other pathways also being involved in linking diabetes to dementia.

While AD pathology is often cited to be present in about two-thirds of patients with dementia, this estimate includes both patients with $\mathrm{AD}$ pathology alone, as well as those with both $\mathrm{AD}$ pathology along with other pathologies such as the pathology of VCID and/or other neurodegenerative dementias (e.g., synucleinopathy, TDP-43, etc). Overall, the most common form of dementia is "mixed dementia", and that mixture is most commonly one of both vascular and neurodegenerative pathology (Schneider et al., 2007). Links between diabetes and AD pathology are also reported but remain poorly understood. Some data from in vivo biomarker studies such as those using neuroimaging and cerebrospinal fluid, suggest that persons with diabetes have more brain atrophy, reduced glucose metabolism, and other changes in markers of neurodegeneration, including alterations in cerebrospinal fluid and phosphorylated tau in particular, that are in keeping with AD (Baker et al., 2011; Moran et al., 2015; Roberts et al., 2014). Mice with knockout of the insulin receptor in the brain show increased tau phosphorylation (Schubert et al., 2004). Data from postmortem brain tissue from elderly individuals have demonstrated the presence of some biochemical features reminiscent of insulin resistance in the hippocampal formation of persons with $\mathrm{AD}$ (with and without diabetes) compared to cognitively normal controls, and this insulin resistance has been reported to be associated with pathology that involves both $\mathrm{A} \beta$ oligomers and fibrillar amyloid plaques (Talbot et al., 2012). Consistent with this is the report that a mouse model that accumulates only $A \beta$ oligomers showed metabolic flexibility that remained relatively intact while another mouse model that accumulated both $\mathrm{A} \beta$ oligomers and fibrils developed features of insulin resistance (Ruiz et al., 2016). A more recent postmortem study has shown that "brain insulin resistance" (a term in need of a precise definition) is associated with tau pathology in $\mathrm{AD}$ as well as other neurodegenerative tauopathies such as corticobasal degeneration (Yarchoan et al., 2014). Finally, some genetic data 
now suggest a link between diabetes and $\mathrm{AD}$, as in the case of the insulin degrading enzyme gene or, more recently the SorCS1 gene which is thought to regulate $\mathrm{A} \beta$ metabolism (Lane et al., 2010; Lane et al., 2013). Thus, amyloidosis, tauopathy, typical AD pathology and/or other neurodegenerative mechanisms -- as well as "brain insulin resistance" (perhaps even apart from peripheral diabetes per se) -- appear to play roles in linking diabetes to dementia, apart from the cerebrovascular mechanisms.

Nonetheless, neuropathological studies have largely failed to confirm a consistent association between diabetes and $\mathrm{AD}$ pathology. Indeed, only a few studies suggest associations with increased $\mathrm{AD}$ pathology, including in subsets of persons such as those who are apolipoprotein E epsilon 4 carriers (MalekAhmadi et al., 2013; Matsuzaki et al., 2010; Peila et al., 2002), but most studies show either no relationship or a relationship with decreased pathology that is modulated by antidiabetic therapies (Ahtiluoto et al., 2010; Alafuzoff et al., 2009; Arvanitakis et al., 2006a; Beeri et al., 2005; Heitner \& Dickson, 1997; Janson et al., 2004; Nelson et al., 2009; Sonnen et al., 2009). There are reports that the clinical cognitive syndrome in diabetes is more dysexecutive rather than amnestic (Arvanitakis et al., 2004; Arvanitakis et al., 2006b; Nandipati et al., 2012), arguing against a strong diabetes-AD connection. In the largest clinicopathological study to date of about 2,400 persons, diabetes was not associated with $\mathrm{AD}$ pathology when assessed using overall measures of $\mathrm{AD}$ and more specific measures of severity of tangle and amyloid pathology (Abner et al., 2016). Whether some individual features of $\mathrm{AD}$ pathology (e.g., A $\beta$ oligomer and/or fibril accumulation) play roles remains unclear. In summary, while an AD mechanism is less established (or perhaps less clinically important) than the vascular mechanism, further elucidation of this pathway may bring insight into other opportunities for treatment and prevention of neurocognitive dysfunction and dementia. Along these lines, both observational studies and experimental clinical trials have examined the role of conventional and unconventional (e.g., intranasal) administration of anti-diabetes medications for treatment of clinical and pathologic AD (Beeri et al., 2008; Craft et al., 2012; Gold et al., 2010; Watson et al., 2005).

Yet other mechanisms underlying the association of diabetes with neurocognitive dysfunction and dementia need to be further explored. While not a widely accepted concept, some researchers suggest that some AD may even be considered a metabolic disease caused by insulin resistance in the brain, separate from diabetes (Rivera et al., 2005), raising yet again the need for an evidencebased definition for "brain insulin resistance". Given the range of effects of insulin in the brain, including neurogenesis, neurite outgrowth, and modulation of catecholamine release/uptake, other possible links between insulin resistance and dementia need to be considered. For examples, mice lacking insulin signaling in brain have been shown to have altered dopamine turnover associated with behavioral changes (Kleinridders et al., 2015). Downstream effects from insulin resistance, whether peripheral or central, could involve increased glucose and advanced glycation end products (AGEs), and alterations in adipokines (e.g., leptin) and other factors (Cherbuin et al., 2012; Holden et al., 2009; Yaffe et al., 2011). Effects of insulin and other factors, including inflammation in the brain, need further consideration as plausible underlying mechanisms linking insulin resistance, with and without diabetes/prediabetes, to dementia.

Even in the absence of vascular and other complications, diabetes can alter synaptic plasticity in the mouse hippocampus resulting in cognitive deficits (Stranahan et al., 2008), and mice with diabetes are less likely to recover from stroke due to impaired neuroplastic mechanisms (Sweetnam et al., 2012). Ongoing studies in humans support the hypothesis that cognitive dysfunction in type 2 diabetes is related to alterations in the mechanisms of cortical brain plasticity (Fried et al., unpublished observations). The mechanisms for altered synaptic plasticity in diabetes are unclear but may be linked to reductions in efficacy of N-methyl-D-aspartate receptor (NMDAR)-dependent mechanisms of plasticity. Diabetes is associated with upregulation of the GLUT1 glucose transporter (Kumagai et al., 1996); glucose provides the original source of glutamate in the brain (Bradford \& Thomas, 1969), and chronic hyperglycemia may thus lead to excessive glutamate and increased risk of excitotoxicity. Any downregulation in post-synaptic NMDARs to moderate this risk would consequently reduce the efficiency of long-term potentiation and alter any NMDARdependent measures. Alterations in the efficacy of the mechanisms of plasticity have also been identified as early pathophysiologic steps in Alzheimer's disease and these may thus represent another link between metabolic disorders and dementia.

\section{Pathophysiology unique to diabetes and its impact on neurocognition}

Studies of the relationships linking diabetes, insulin resistance, and neurocognitive dysfunction have largely focused on how peripheral metabolism impacts brain function. Unlike other complications of diabetes (e.g., neuropathy, retinopathy, nephropathy), neurocognitive complications of diabetes have not clearly been demonstrated to correlate with measures of peripheral glycemia (with the exception of very poor glycemic control, HbA1c $>10 \%$ and a potential role for glycemic variability) and there is only limited evidence for a modest association with other measures of peripheral glucose regulation (e.g., insulin concentration, insulin action, insulin resistance) (Geijselaers et al., 2015). It is possible that there are central mechanisms that will better account for the neurocognitive dysfunction observed in diabetes and other metabolic disease. One promising line of research has central insulin and insulin-like growth factor 1 (IGF-1) in the spotlight. There is evidence that disrupted central insulin and IGF-1 signaling may lead to disrupted neurotransmitter (e.g., dopamine) and astroglial cell function, brain endothelial cell function involved in formation and regulation of blood-brain barrier (BBB), mitochondrial metabolism and oxidative stress, regulation of the phosphorylation of microtubule-associated tau protein and clearance of $A \beta$ and/or amyloid fibrils, cholesterol synthesis in the 
brain (important for myelination and membrane function), glucose and lipid metabolism in select regions of the brain, and regulation of central energy balance, which could relate to both metabolic and neurocognitive dysfunction (Bingham et al., 2002; Brüning et al., 2000; Convit et al., 2003; Kleinridders et al., 2015; Liu et al., 2013; Montagne et al., 2015; Schubert et al., 2004; Stouffer et al., 2015; Suzuki et al., 2010; Suzuki et al., 2013). Restoring insulin function in the brain via intranasal insulin is now being tested as a potential therapeutic option for neurocognitive dysfunction in both diabetes and dementia separately (Claxton et al., 2015; Novak et al., 2014) and repurposing diabetes drugs for use in dementia has also been proposed (Yarchoan \& Arnold, 2014). However, more research in this area is critically needed. For example, it has been suggested that the reduced insulin signaling observed in aging, and exacerbated in $\mathrm{AD}$, results from a neuroprotective mechanism (Steculorum et al., 2014). This view derives from evidence that decreased insulin signaling promotes life-extension in C. elegans (Kenyon et al., 1993) and that genetically induced insulin resistance has positive effects on cognition in an animal model of AD (Killick et al., 2009). If so, then intranasal insulin treatment may produce short term benefits but deleterious effects in the long term.

The physiological neuroendocrine mechanism(s) that may participate in the intersection between diet, obesity, diabetes, and dementia is less clear; however, there are a few intriguing mechanisms to consider. Insulin modulates synaptic plasticity of dopamine neurons to regulate reward function and food intake behavior (Stouffer et al., 2015), as well as behaviors of anxiety and depression (Kleinridders et al., 2015) and hyperinsulinemia may lead to ineffective regulation of dopamine and increased food intake (Liu et al., 2013). It is also possible that hormonal changes that occur in obesity and diabetes, such as disrupted glucocorticoid function, could impact synaptic plasticity and brain function (Bocarsly et al., 2015). Impaired neuroplasticity itself, via a glucocorticoid-related or other mechanism(s), could account for metabolic and neurocognitive dysfunction (Oberman \& Pascual-Leone, 2013; Pascual-Leone et al., 2011; Stranahan et al., 2008; Wosiski-Kuhn et al., 2014). There is also evidence that corticotropin-releasing factor regulates cerebral amyloid accumulation along an as yet undefined pathway that is glucocorticoid-independent (Macauley et al., 2015).

Microglial dysfunction has become a central point for investigation in $\mathrm{AD}$, since about one-third of genes associated with $\mathrm{AD}$ are expressed at high levels or exclusively by microglia. Glucocorticoids appear to impact microglia activation and the release of pro-inflammatory cytokines, which may result in neuroinflammation and cognitive dysfunction (Dey et al., 2014; Erion et al., 2014; Hao et al., 2016). Somewhat unexpectedly, the gut microbiome has been recently revealed as a potential modulator of physiological function of microglia, and research in other neurodegenerative diseases and Parkinson Disease in particular, have suggested a gut-brain mechanism of disease (Erny et al., 2015).
Mechanisms linking diet, obesity, and neurocognition There has been even less appreciation for how diet and obesity may adversely impact brain function in the absence of diabetes or dementia. Obesity has been associated with altered brain structure and function in animal models and in metabolically and neurologically healthy adults and children (Bocarsly et al., 2015; Hsu \& Kanoski, 2014; Yau et al., 2014). Consumption of a high fat diet (HFD) can also negatively impact the brain and cognitive function well before obesity onset (Hsu \& Kanoski, 2014). Indeed, obesity can impact cognition independently from metabolic disease and diet can impact metabolic function and cognition independently of obesity. Recent data suggest that weight reduction may even improve neurocognitive function (Horie et al., 2016). It will therefore be important to look beyond disease states to examine the influence of diet and obesity on neurocognitive function more generally.

Although obesity is occasionally associated with global measures of brain atrophy (Brooks et al., 2013; Enzinger et al., 2005; Raji et al., 2010) and cognitive decline, many studies suggest that executive function and learning and memory are most affected in both adults and children (Fitzpatrick et al., 2013; Francis \& Stevenson, 2013; Gunstad et al., 2007; Sabia et al., 2009). Corresponding with this neuropsychological profile, structural changes are observed in the parietal and prefrontal cortex (important for executive function), as well as the entorhinal cortex and hippocampus (important for learning/memory) (Enzinger et al., 2005; Fotuhi et al., 2012; Hao et al., 2016; Miller \& Spencer, 2014; Pannacciulli et al., 2006; Raji et al., 2010). These changes may be a consequence rather than a cause of obesity, as supported by neuroimaging data in the minipig animal model (Val-Laillet et al., 2011). Cerebral blood flow, a marker of neuronal activity, is significantly lower in the dorsolateral and anterior prefrontal cortex in minipigs with diet induced obesity compared to their lean counterparts. Likewise, in humans, there is reduced cortical thickness in the prefrontal, temporal and parietal cortex in adults but not in children (Sharkey et al., 2015), suggesting that structural changes occur after chronic HFD, metabolic disease and/or obesity. Teasing apart these three factors is an important avenue for future work.

HFD and obesity are also associated with dopamine-dependent mesocorticolimbic-prefrontal alterations that may impact reward learning, motivation, and executive functions (Johnson \& Kenny, 2010; Sevgi et al., 2015; Stice et al., 2008; Sun et al., 2015; Vainik et al., 2013). Overweight/obese compared to healthy weight individuals show reduced change in striatal D2R binding potential in response to glucose ingestion (consistent with reduced dopamine release) and several studies have reported a negative association between basal metabolic index and the blood oxygen level dependent (BOLD) response to milkshake consumption in the dorsal striatum. Although BOLD does not directly measure dopamine release, the effect is dependent upon the Taq1a A1 polymorphism, which affects D2 receptor density, thus linking the BOLD response to abnormal 
D2R signaling which can also be linked to heightened impulsivity (Babbs et al., 2013). Along this line, there are emerging data that suggest specific macronutrients or combinations of macronutrients have selective effects on dopamine adaptations. One can speculate on the development of "vicious cycles" that lead to obesity, driven by both genetic makeup, dietary composition, and other factors.

Similar to the association between diabetes and AD, "brain insulin resistance" may play a key role. Insulin action directly affects central glucose metabolism and is posited to influence learning and memory by modulating synaptic plasticity, density, neurotransmission and adult neurogenesis. As such, intranasal administration improves cognition in healthy individuals (Benedict et al., 2004), raising the possibility that the reverse is also true; that is, decreased insulin signaling associated with sub-clinical insulin resistance accounts for the cognitive dysfunction observed following a HFD or obesity in otherwise healthy individuals. Supporting this hypothesis, a functional type of "brain insulin resistance" has been associated with hypo-active responses in obese non-diabetic, cognitively intact, people within fronto-parietal circuits, which are critical for working memory (the ability to hold and manipulate new and old information "on-line"). Working memory is markedly impaired in overweight and obese individuals and insulin sensitivity mediates a negative association between body mass index (BMI) and response in the fronto-parietal circuit during a working memory task (Gonzales et al., 2010). Diet-induced obesity can also influence insulin resistance in the hippocampus and likely elsewhere in the brain where insulin receptors are expressed, such as the amygdala and midbrain (McNay et al., 2010). Thus, metabolic alterations may impact brain function well before the onset of metabolic disorders, and weight reduction may improve both metabolic state and cognition (Horie et al., 2016).

Typical peripheral insulin resistance is often correlated with a number of other factors associated with diet-induced obesity that may also cause neurocognitive dysfunction. Obesity and HFD lead to systemic and central inflammation with elevated circulating IL-12 and IL-6, both of which have been linked to impaired processing speed and executive function, even independently of metabolic risk factors (Gregor \& Hotamisligil, 2011; Thaler \& Schwartz, 2010; Trollor et al., 2012). Thus, several groups have highlighted inflammation as "the pathway to cognitive impairment" (Miller \& Spencer, 2014; Steculorum et al., 2014). Hypersecretion of glucocorticoids may also contribute. The hypothalamic-pituitary-adrenal axis, which is altered in obesity, regulates glucocorticoid secretion, and has in turn been associated with mood changes, memory impairment, and reduced hippocampal volume (MacQueen \& Frodl, 2011; Raber, 1998).

Emerging work also suggests that diet-induced BBB disruption may provide a mechanistic link involving diet, obesity and hippocampal-dependent cognitive functions (Hsu \& Kanoski, 2014). Rats fed a HFD for 90 days show decreased expression of
BBB tight junction proteins and the presence of sodium fluorescin, a fluorescent-tagged molecule normally excluded from the brain by the $\mathrm{BBB}$ and choroid plexus, was found in the hippocampus but not in the prefrontal cortex or striatum (Kanoski et al., 2010). More recently, Davidson and colleagues found sodium fluorescin in the hippocampus of rats that failed to show a reversal of diet-induced impairments in hippocampal-dependent tasks upon HFD discontinuation, while rats demonstrating recovery of function did not (Davidson et al., 2012). Some evidence indicates that BBB integrity may influence learning and memory by affecting the passage of nutrients and neuroendocrine signals such as insulin, leptin and ghrelin from the periphery to the brain.

\section{Neurocognitive dysfunction affecting food intake behavior and obesity}

Many of the brain adaptations produced by diet, obesity and metabolic dysfunction lead to neurocognitive and behavioral changes that may confer additional risk for obesity (Higgs et al., 2012; Higgs, 2015a; Higgs, 2015b; Sellbom \& Gunstad, 2012; Vainik et al., 2013), leading to what has been described as a "vicious cycle of obesity, metabolic disease, and cognitive decline" (Davidson et al., 2014). Insensitivity to satiety can disrupt habituation or the drop in appetitive responses to foods that accompany eating and there is evidence that the hippocampus plays a role (Small et al., 2001). Work in rodents has also focused on the role of the hippocampus in sensing the internal state. In an associative learning model, diet-induced damage to the hippocampus may disrupt the ability of interoceptive satiety states to serve as contextual stimuli signaling that a food is not rewarding in a sated state (Davidson et al., 2014). This, in turn, leads to positive energy balance by promoting eating in the absence of hunger.

The decreased responses in fronto-parietal circuits and corresponding executive function impairments have long been implicated in inhibitory control of feeding behavior (Alonso-Alonso \& Pascual-Leone, 2007; Le et al., 2006). Adaptations in these circuits may therefore further promote overeating, especially in the modern food environment where self-control is especially taxed. In addition, decisions to eat depend upon multiple interacting factors besides hunger and hedonics. Habits, time of day, heath concerns, peer pressure, and stress are amongst the other important modulators. The prefrontal cortex is critical for integrating these factors so that long-term goals can override hedonic and homeostatic signals.

Thus, while strong evidence links obesity to brain dysfunction, the extent to which this arises directly from adiposity, diet, metabolic dysfunction, or other factors is incompletely understood and future research in this area is needed.

\section{Some research areas in need of increased attention Early development}

The role of early development, in particular, appears to be critical in understanding the link between obesity, metabolic disease, 
and neurocognitive dysfunction. Maternal obesity and metabolic disease, and diet during pregnancy may impact the child in utero and lead to a greater risk for childhood obesity, metabolic dysfunction, and neurodevelopmental disruption (Linder et al., 2015; Rivera et al., 2015). High-fat feeding of pregnant and nursing mice has been shown to have important effects of hypothalamic neurocircuit formation that impacts adult brain function (Vogt et al., 2014). Intervention in early development is critical as there is now evidence that dysregulated metabolic function and obesity lead to detectable brain and cognitive changes in young children, may disrupt academic performance, and could lead to challenges in transitioning to independence and successful adulthood (Mauras et al., 2015; Mazaika et al., 2016; Semenkovich et al., 2015; Yau et al., 2012; Yau et al., 2014).

\section{Type 1 diabetes}

While the association between type 2 diabetes and dementia has been reported for some time, there has been less attention paid to whether type 1 diabetes may be associated with dementia. We now know that childhood-onset type 1 diabetes leads to detectable brain and cognitive changes in early life through middle adulthood (Mauras et al., 2015; Mazaika et al., 2016; Nunley et al., 2015a; Nunley et al., 2015b; Ryan et al., 2015; Semenkovich et al., 2015), including changes in brain fMRI (Musen et al., 2008). It will be important to understand how glycemic dysregulation over the lifecourse impacts neurocognitive function, disease management, and risk for dementia. Iatrogenic hypoglycemia may play some role(s) that remain to be clarified.

\section{Relationships among central and peripheral insulin signaling} and metabolism

A complex and confusing literature has already accumulated wherein no obvious single, simple model adequately explains the bidirectional relationships linking central and peripheral insulin signaling and metabolism. Because of this, we are not attempting to summarize all that literature here. However, we would refer the reader to Ishii \& Iadecola (2015b), (Ruiz et al., 2016), and (Knight et al., 2016). The former provides an outstanding summary of the primary and secondary involvement of the hypothalamus in $\mathrm{AD}$, while the latter two provide examples of the largely unappreciated metabolic dysfunction present in standard models of AD pathology and the unexpected effects that can result when either the $\mathrm{AD}$ pathology, the metabolic pathology, or both, are manipulated.

\section{Some broad research needs}

The workshop concluded with discussion of the research presented and reviewed above in order to identify research needs to move the field forward. Below is a list of the most important research needs identified at the workshop.

- Improved tools and model systems for drug discovery and development
- Increased utilization of existing tools and model systems for mechanistic research

- Deep metabolic and neurocognitive phenotyping in human studies

- Improved biomarkers for use in human studies

- Increased utilization of existing biomarkers for human studies

- Improved human neuroimaging technologies

- Detailed metabolomics analysis of individual brain regions in both diabetes and dementia, using techniques such as imaging mass spectrometry

- Increased utilization of existing, novel human neuroimaging technologies

- Longitudinal human studies assessing cognition, metabolism and diet

- Human studies manipulating diet to determine causality and identify specific aspects of foods (e.g. macronutrients such as saturated fatty acids) that negatively impact brain and brain function

- An operational definition of "brain insulin resistance" and tools for measuring brain insulin signaling in vivo

- Better understanding of insulin action on astroglial versus neuronal cells as this relates to altered brain function in diabetes

- Development of a protocol to define and measure a "brain health index" for persons with metabolic dysfunction

- Need for harmonization and standardization across measures and protocols

- Combined human, animal, and cell culture studies

- Increased attention to gut-brain signaling, microbiome, and the relationship to obesity, metabolic disease, and neurocognitive dysfunction

- Evaluation of weight loss and diet for reversing or improving cognition

- Interdisciplinary teams collaborating on research at the intersection of metabolism and brain dysfunction

- Engaging and maintaining junior researchers in the field 


\section{Future directions}

Now is a critical period for research in the field of metabolic and neurocognitive dysfunction. Major complementary efforts, including the Brain Research Through Advancing Innovative Neurotechnologies (BRAIN) initiative, the National Plan to Address Alzheimer's Disease (NAPA), the Big Data to Knowledge (BD2K) initiative, and the Precision Medicine Initiative (PMI), will provide the financial support, tools, and scientific communities that are poised to substantially advance mechanistic research linking metabolic disease and neurocognitive dysfunction within the next dozen or so years. The scientific challenge here is to determine the mechanism(s) that explain the interactions between metabolism, the brain, and neurocognitive dysfunction, in order to identify methods for early detection of risk for metabolic and neurocognitive dysfunction and potential strategies and critical periods for prevention, mitigation, and intervention for these diseases. Figure 1 illustrates the most plausible biological mechanisms that may explain the bidirectional relationship between metabolic and neurocognitive dysfunction. These include mechanisms at the molecular, cellular, organ and tissue-based, and systemic levels, which may lead to metabolic and neurcognitive dysregulation that underlies disease processes contributing to obesity, insulin resistance, prediabetes, type 2 diabetes, and dementia (including VCID, $\mathrm{VaD}, \mathrm{AD}$, and others). In addition, these factors may be modified by other biological, behavioral, and environmental factors, which may be targets to optimize health outcomes. Public policy can serve as the ultimate modifier of these various risk factors, and will determine the success of the major effort required to prevent these common co-morbid diseases that are increasingly likely to burden our aging population.

An important step toward that goal is to take a highly heterogeneous group of individuals with metabolic and neurocognitive dysfunction and begin to cluster them into more homogeneous subgroups based on detailed clinical, metabolic, and neurocognitive data. This includes the need for more human brain specimens from individuals with good physiological characterization regarding diabetes, metabolic function, and neurocognitive function throughout the lifespan. This would allow preclinical researchers to test potential mechanisms based on distinct, relevant metabolic and neurocognitive abnormalities and develop prevention and treatment strategies targeting these phenotypes. Animal models will be an important contribution to these preclinical studies and should have comparable abnormalities in conserved domains compared to humans. For example, in rodents, it is reasonable to assume that learning and memory functions are somewhat comparable to humans, but it is unlikely that executive functions and decision-making (and the neural circuits that support these functions) are similar between species. Finally, a more homogeneous cluster of individuals with shared metabolic and neurocognitive resilience, risk or disease factors are allocated to targeted prevention and intervention efforts based on shared mechanisms to optimize prevention, mitigation, and treatment of the neurocognitive complications of diabetes and related metabolic dysfunction. In many ways, we already have the tools and technologies in place to perform deep phenotyping to guide future efforts for targeted, individualized therapies. Recently, it was discovered based on genetic analyses, that type 2 diabetes may in fact consists of 3 subtypes and that one specific subtype appears to be associated with neurological disease ( $\mathrm{Li}$ et al., 2015). This type 2 diabetes subtype was also associated with cardiovascular disease, but not diabetic retinopathy or nephropathy, which implies that the mechanisms for neurocognitive complications of diabetes differ from complications in other end organs. There are related efforts, methods, and tools in development that could be leveraged for further discovery into the mechanisms at the interface of metabolic and neurocognitive function, including in the areas of neuroimaging (Yeo et al., 2016) and neuroimaging genetics (Thompson et al., 2014), web-based cognitive testing (Germine et al., 2012), and individualized neural and physiological phenotyping over time (Poldrack et al., 2015; Wang et al., 2015; Yeo et al., 2016).

\section{Author contributions}

L.E.S., Z.A., S.G., and D.S. wrote the first draft, revised, and edited the White Paper. Other named authors read and edited the paper. All authors approved the content.

\section{Competing interests}

No competing interests were disclosed.

\section{Grant information}

The following National Institutes of Health grant funding supported this work: R01 NS084965 (Z.A.); U01AG046170 (S.G.; Eric Schadt); R01 DK 085579 (D.S.); P50 AG005138 (S.G.; Mary Sano, PI); R01 CA 180030 (D.S.); R01 NS075685 (S.G.); R01 DC 006706 (D.S.); P30 AG10161 (Z.A. David A. Bennett, PI); R01 AG 040039 (Z.A.); R21 NS082870 (A.P.L.).

\section{Acknowledgements}

This White Paper was submitted on behalf of the participants of the National Institute of Diabetes, Digestive, and Kidney Diseases Workshop "The Intersection of Metabolic and Neurocognitive Dysfunction" in July 2015. For details of the workshop program, see the Supplementary File 1. Thank you to Mr. Alan Hoofring (Lead Medical Illustrator, NIH) for his graphics expertise in the creation of Figure 1. 


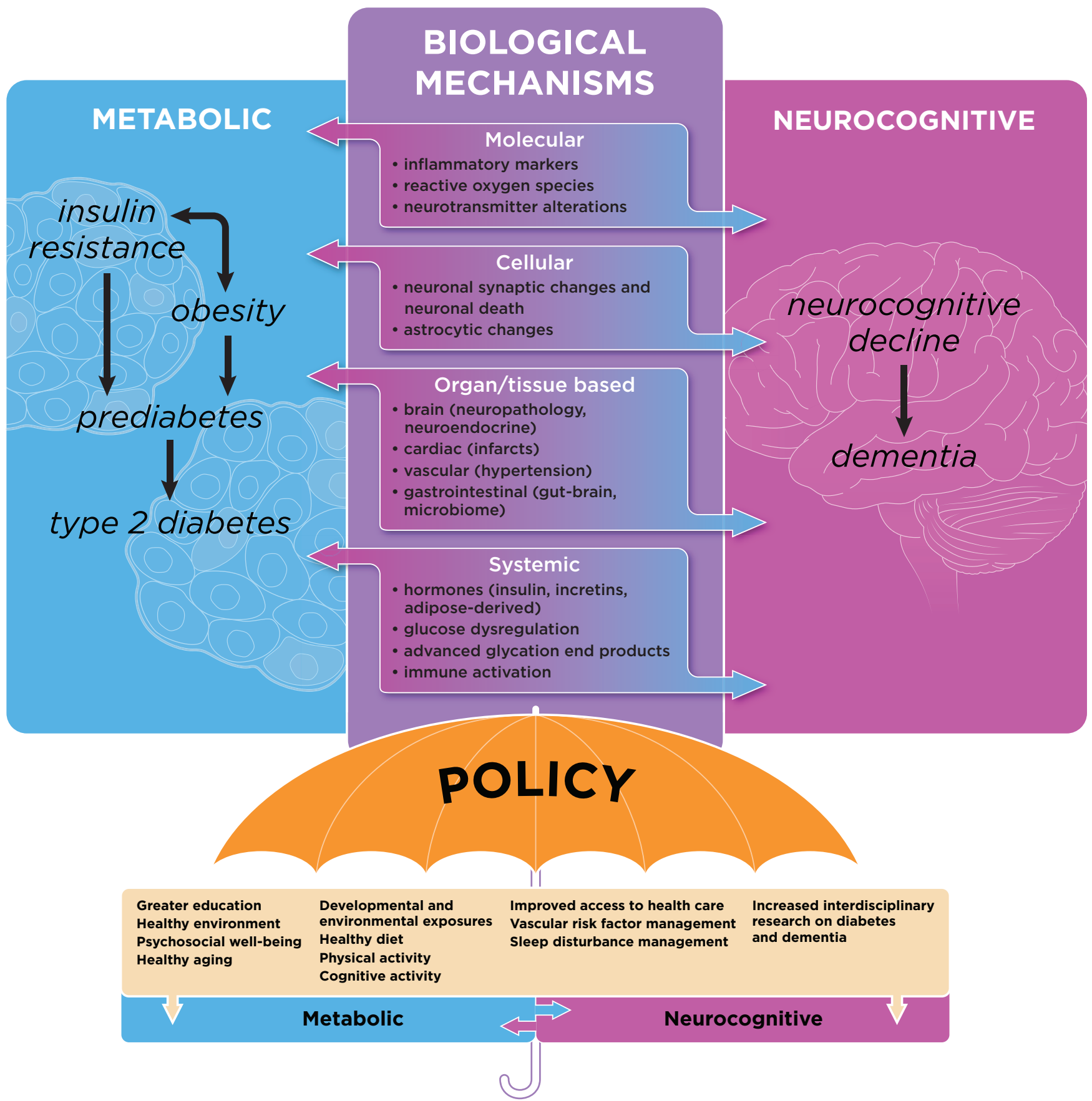

Figure 1. Possible mechanisms explaining the bidirectional relationship between metabolic and neurocognitive dysfunction. The most plausible biological mechanisms (middle panel: molecular, cellular, organ and tissue-based, systemic) are shown that may explain the bidirectional relationship between metabolic (left panel: obesity, insulin resistance, prediabetes, type 2 diabetes) and neurocognitive dysfunction, including dementia (right panel: e.g., VCID, VaD, AD, other). Genetic and epigenetic mechanisms (not represented in the figure) likely trigger the pathophysiological processes underlying metabolic and neurocognitive dysfunction (represented by the innermost circle), and these disease processes, in turn, may be modified by other factors (listed under the "policy" umbrella), which may be targets to maximize health outcomes and behaviors. Finally, public policy (including health policy and health care management) is the societal tool that can serve as the ultimate modifier of these various risk factors, and will determine the success of the major effort required to prevent these common co-morbid diseases that are increasingly likely to burden our aging population. 


\section{Supplementary material}

Supplementary File 1: Workshop Program. Details of participants and talks at the National Institute of Diabetes and Digestive and Kidney Diseases (NIDDK) The Intersection of Metabolic and Neurocognitive Dysfunction Workshop.

Abbott RD, Donahue RP, MacMahon SW, et al:: Diabetes and the risk of stroke. The Honolulu Heart Program. JAMA. 1987; 257(7): 949-952.

PubMed Abstract | Publisher Full Text

Abner EL, Nelson PT, Kryscio RJ, et al.: Diabetes is associated with cerebrovascular but not Alzheimer neuropathology. Alzheimers Dement. 2016; pii: S1552-5260(15)03030-7.

PubMed Abstract | Publisher Full Text

Ahtiluoto S, Polvikoski T, Peltonen M, et al.: Diabetes, Alzheimer disease, and vascular dementia: a population-based neuropathologic study. Neurology. 2010; 75(13): 1195-1202.

PubMed Abstract | Publisher Full Text

Alafuzoff I, Aho L, Helisalmi S, et al.: Beta-amyloid deposition in brains of subjects with diabetes. Neuropathol Appl Neurobiol. 2009; 35(1): 60-68. PubMed Abstract | Publisher Full Text

Alonso-Alonso M, Pascual-Leone A: The right brain hypothesis for obesity. JAMA. 2007; 297(16): 1819-1822.

PubMed Abstract | Publisher Full Text

Arvanitakis Z, Schneider JA, Wilson RS, et al:: Diabetes is related to cerebral infarction but not to AD pathology in older persons. Neurology. 2006a; 67(11): 1960-1965.

PubMed Abstract | Publisher Full Text

Arvanitakis Z, Wilson RS, Bienias $\mathrm{JL}$, et al: Diabetes mellitus and risk of Alzheimer disease and decline in cognitive function. Arch Neurol. 2004; 61(5): 661-666. PubMed Abstract | Publisher Full Text

Arvanitakis Z, Wilson RS, Li Y, et al:: Diabetes and function in different cognitive systems in older individuals without dementia. Diabetes Care. 2006b; 29(3): $560-565$

PubMed Abstract | Publisher Full Text

Babbs RK, Sun X, Felsted J, et al: Decreased caudate response to milkshake is associated with higher body mass index and greater impulsivity. Physiol Behav. 2013: 121: 103-111.

PubMed Abstract | Publisher Full Text | Free Full Text

Baker LD, Cross DJ, Minoshima S, et al.: Insulin resistance and Alzheimer-like reductions in regional cerebral glucose metabolism for cognitively normal adults with prediabetes or early type 2 diabetes. Arch Neurol. 2011; 68(1): 51-57. PubMed Abstract | Publisher Full Text | Free Full Text

Banerjee C, Moon YP, Paik MC, et al:: Duration of diabetes and risk of ischemic stroke: the Northern Manhattan Study. Stroke. 2012; 43(5): 1212-1217. PubMed Abstract | Publisher Full Text | Free Full Text

Bateman RJ, Xiong C, Benzinger TL, et al:: Clinical and biomarker changes in dominantly inherited Alzheimer's disease. N Engl J Med. 2012; 367(9): 795-804. PubMed Abstract | Publisher Full Text | Free Full Text

Beeri MS, Schmeidler J, Silverman JM, et al:: Insulin in combination with other diabetes medication is associated with less Alzheimer neuropathology. Neurology. 2008; 71(10): 750-757.

PubMed Abstract | Publisher Full Text | Free Full Text

Beeri MS, Silverman JM, Davis KL, et al:: Type 2 diabetes is negatively associated with Alzheimer's disease neuropathology. J Gerontol A Biol Sci Med Sci. 2005; 60(4): 471-475

PubMed Abstract | Publisher Full Text | Free Full Text

Benedict C, Hallschmid M, Hatke A, et al:: Intranasal insulin improves memory in humans. Psychoneuroendocrinology. 2004; 29(10): 1326-1334.

PubMed Abstract | Publisher Full Tex

Biessels GJ, Reagan LP: Hippocampal insulin resistance and cognitive dysfunction. Nat Rev Neurosci. 2015; 16(11): 660-671.

PubMed Abstract | Publisher Full Text

Biessels GJ, Strachan MW, Visseren FL, et al.: Dementia and cognitive decline in type 2 diabetes and prediabetic stages: towards targeted interventions. Lancet Diabetes Endocrinol. 2014; 2(3): 246-255.

PubMed Abstract | Publisher Full Text

Bingham EM, Hopkins D, Smith D, et al.: The role of insulin in human brain glucose metabolism: an ${ }^{18}$ fluoro-deoxyglucose positron emission tomography study. Diabetes. 2002; 51(12): 3384-3390.

PubMed Abstract | Publisher Full Text

Bocarsly ME, Fasolino M, Kane GA, et al.: Obesity diminishes synaptic markers, alters microglial morphology, and impairs cognitive function. Proc Natl Acad Sci U S A. 2015; 112(51): 15731-15736.

PubMed Abstract | Publisher Full Text | Free Full Text
Bradford HF, Thomas AJ: Metabolism of glucose and glutamate by synaptosomes from mammalian cerebral cortex. J Neurochem. 1969; 16(11) 1495-1504

PubMed Abstract | Publisher Full Text

Brooks SJ, Benedict C, Burgos J, et al: Late-life obesity is associated with smaller global and regional gray matter volumes: a voxel-based morphometric study. Int J Obes (Lond). 2013; 37(2): 230-236.

PubMed Abstract | Publisher Full Text | Free Full Text

Brundel M, Kappelle LJ, Biessels GJ: Brain imaging in type 2 diabetes. Eur Neuropsychopharmacol. 2014; 24(12): 1967-1981.

PubMed Abstract | Publisher Full Text

Brüning JC, Gautam D, Burks DJ, et al.: Role of brain insulin receptor in control of body weight and reproduction. Science. 2000; 289(5487): 2122-2125.

PubMed Abstract | Publisher Full Text

Cherbuin N, Sachdev P, Anstey KJ: Higher normal fasting plasma glucose is associated with hippocampal atrophy: The PATH Study. Neurology. 2012; 79(10): 1019-1026.

PubMed Abstract | Publisher Full Text

Claxton A, Baker LD, Hanson A, et al:: Long-acting intranasal insulin detemir improves cognition for adults with mild cognitive impairment or early-stage Alzheimer's disease dementia. J Alzheimers Dis. 2015; 44(3): 897-906.

PubMed Abstract | Publisher Full Text

Convit A, Wolf OT, Tarshish C, et al:: Reduced glucose tolerance is associated with poor memory performance and hippocampal atrophy among normal elderly. Proc Natl Acad Sci U S A. 2003; 100(4): 2019-2022.

PubMed Abstract | Publisher Full Text | Free Full Text

Craft S, Baker LD, Montine TJ, et al.: Intranasal insulin therapy for Alzheimer disease and amnestic mild cognitive impairment: a pilot clinical trial. Arch Neurol. 2012; 69(1): 29-38.

PubMed Abstract | Publisher Full Text | Free Full Text

Davidson TL, Monnot A, Neal AU, et al.: The effects of a high-energy diet on hippocampal-dependent discrimination performance and blood-brain barrier integrity differ for diet-induced obese and diet-resistant rats. Physiol Behav. 2012; 107(1): 26-33.

PubMed Abstract | Publisher Full Text | Free Full Text

Davidson TL, Sample CH, Swithers SE: An application of Pavlovian principles to the problems of obesity and cognitive decline. Neurobiol Learn Mem. 2014; 108 : 172-184.

PubMed Abstract | Publisher Full Text | Free Full Text

Dey A, Hao S, Erion JR, et al:: Glucocorticoid sensitization of microglia in a genetic mouse model of obesity and diabetes. J Neuroimmunol. 2014; 269(1-2): 20-27.

PubMed Abstract | Publisher Full Text | Free Full Text

Enzinger C, Fazekas F, Matthews PM, et al: Risk factors for progression of brain atrophy in aging: six-year follow-up of normal subjects. Neurology. 2005 64(10): 1704-1711

PubMed Abstract | Publisher Full Tex

Erion JR, Wosiski-Kuhn M, Dey A, et al: Obesity elicits interleukin 1-mediated deficits in hippocampal synaptic plasticity. J Neurosci. 2014; 34(7): 2618-2631. PubMed Abstract | Publisher Full Text | Free Full Text

Erny D, Hrabě de Angelis AL, Jaitin D, et al:: Host microbiota constantly control maturation and function of microglia in the CNS. Nat Neurosci. 2015; 18(7): 965-977.

PubMed Abstract | Publisher Full Text

Fitzpatrick S, Gilbert S, Serpell L: Systematic review: are overweight and obese individuals impaired on behavioural tasks of executive functioning? Neuropsychol Rev. 2013; 23(2): 138-156.

PubMed Abstract | Publisher Full Text

Fotuhi M, Do D, Jack C: Modifiable factors that alter the size of the hippocampus with ageing. Nat Rev Neurol. 2012; 8(4): 189-202.

PubMed Abstract | Publisher Full Text

Francis $\mathrm{H}$, Stevenson $\mathrm{R}$ : The longer-term impacts of Western diet on human cognition and the brain. Appetite. 2013; 63: 119-128.

PubMed Abstract | Publisher Full Text

Franke $\mathrm{K}$, Gaser $\mathrm{C}$, Manor B, et al:: Advanced BrainAGE in older adults with type 2 diabetes mellitus. Front Aging Neurosci. 2013; 5: 90

PubMed Abstract | Publisher Full Text | Free Full Tex

Geijselaers SL, Sep SJ, Stehouwer CD, et al.: Glucose regulation, cognition, and 
brain MRI in type 2 diabetes: a systematic review. Lancet Diabetes Endocrinol. 2015; 3(1): 75-89.

PubMed Abstract | Publisher Full Text

Germine L, Nakayama K, Duchaine BC, et al.: Is the Web as good as the lab? Comparable performance from Web and lab in cognitive/perceptual experiments. Psychon Bull Rev. 2012; 19(5): 847-857.

PubMed Abstract | Publisher Full Text

Gold M, Alderton C, Zvartau-Hind M, et al:: Rosiglitazone monotherapy in mildto-moderate Alzheimer's disease: results from a randomized, double-blind, placebo-controlled phase III study. Dement Geriatr Cogn Disord. 2010; 30(2): 131-146.

PubMed Abstract | Publisher Full Text | Free Full Text

Gonzales MM, Tarumi T, Miles SC, et al:: Insulin sensitivity as a mediator of the relationship between BMI and working memory-related brain activation. Obesity (Silver Spring). 2010; 18(11): 2131-2137.

PubMed Abstract | Publisher Full Text

Gorelick PB, Scuteri A, Black SE, et al:: Vascular contributions to cognitive impairment and dementia: a statement for healthcare professionals from the American Heart Association/American Stroke Association. Stroke. 2011; 42(9): 2672-2713.

PubMed Abstract | Publisher Full Text | Free Full Text

Gregor MF, Hotamisligil GS: Inflammatory mechanisms in obesity. Annu Rev Immunol. 2011; 29: 415-445.

PubMed Abstract | Publisher Full Text

Gunstad J, Paul RH, Cohen RA, et al:: Elevated body mass index is associated with executive dysfunction in otherwise healthy adults. Compr Psychiatry. 2007; 48(1): $57-61$

PubMed Abstract | Publisher Full Text

Hao S, Dey A, Yu X, et al:: Dietary obesity reversibly induces synaptic stripping by microglia and impairs hippocampal plasticity. Brain Behav Immun. 2016; 51: 230-239.

PubMed Abstract | Publisher Full Text | Free Full Text

Heitner J, Dickson D: Diabetics do not have increased Alzheimer-type pathology compared with age-matched control subjects. A retrospective postmortem immunocytochemical and histofluorescent study. Neurology. 1997; 49(5): 1306-1311.

PubMed Abstract | Publisher Full Text

Higgs S, Rutters F, Thomas JM, et al.: Top down modulation of attention to food cues via working memory. Appetite. 2012; 59(1): 71-75.

PubMed Abstract | Publisher Full Text

Higgs S: Cognitive processing of food rewards. Appetite. 2015a; pii: S01956663(15)30054-4.

PubMed Abstract | Publisher Full Text

Higgs S: Manipulations of attention during eating and their effects on late snack intake. Appetite. 2015b; 92: 287-294.

PubMed Abstract | Publisher Full Text

Holden KF, Lindquist K, Tylavsky FA, et al: Serum leptin level and cognition in the elderly: Findings from the Health ABC Study. Neurobiol Aging. 2009; 30(9): 1483-1489.

PubMed Abstract | Publisher Full Text

Horie NC, Serrao VT, Simon SS, et al:: Cognitive Effects of Intentional Weight

Loss in Elderly Obese Individuals With Mild Cognitive Impairment. J Clin

Endocrinol Metab. 2016; 101(3): 1104-12.

PubMed Abstract | Publisher Full Text

Hsu JL, Chen YL, Leu, JG, et al.: Microstructural white matter abnormalities in type 2 diabetes mellitus: a diffusion tensor imaging study. Neuroimage. 2012; 59(2): 1098-1105.

PubMed Abstract | Publisher Full Text

Hsu TM, Kanoski SE: Blood-brain barrier disruption: mechanistic links between

Western diet consumption and dementia. Front Aging Neurosci. 2014; 6: 88

PubMed Abstract | Publisher Full Text | Free Full Text

Ishii M, ladecola C: Adipocyte-derived factors in age-related dementia and their contribution to vascular and Alzheimer pathology. Biochim Biophys Acta. 2015a; pii: S0925-4439(15)00329-4.

PubMed Abstract | Publisher Full Text

Ishii M, ladecola C: Metabolic and Non-Cognitive Manifestations of Alzheimer's

Disease: The Hypothalamus as Both Culprit and Target of Pathology. Cell

Metab. 2015b; 22(5): 761-776.

PubMed Abstract | Publisher Full Text | Free Full Text

Ivan CS, Seshadri S, Beiser A, et al.: Dementia after stroke: the Framingham

Study. Stroke. 2004; 35(6): 1264-1268.

PubMed Abstract | Publisher Full Tex

Janson J, Laedtke T, Parisi JE, et al:: Increased risk of type 2 diabetes in

Alzheimer disease. Diabetes. 2004; 53(2): 474-481.

PubMed Abstract | Publisher Full Tex

Johnson PM, Kenny PJ: Dopamine D2 receptors in addiction-like reward dysfunction and compulsive eating in obese rats. Nat Neurosci. 2010; 13(5): 635-641.

PubMed Abstract | Publisher Full Text | Free Full Text

Kanoski SE, Zhang Y, Zheng W, et al:: The effects of a high-energy diet on hippocampal function and blood-brain barrier integrity in the rat. $J$ Alzheimers Dis. 2010; 21(1): 207-219.

PubMed Abstract | Publisher Full Text
Kenyon C, Chang J, Gensch E, et al.: A C. elegans mutant that lives twice as long as wild type. Nature. 1993; 366(6454): 461-464.

PubMed Abstract | Publisher Full Text

Killick R, Scales G, Leroy K, et al:: Deletion of Irs2 reduces amyloid deposition and rescues behavioural deficits in APP transgenic mice. Biochem Biophys Res Commun. 2009; 386(1): 257-262.

PubMed Abstract | Publisher Full Text | Free Full Text

Kleinridders A, Cai W, Cappellucci L, et al.: Insulin resistance in brain alters dopamine turnover and causes behavioral disorders. Proc Natl Acad Sci U S A. 2015; 112(11): 3463-3468.

PubMed Abstract | Publisher Full Text | Free Full Text

Knight EM, Ruiz HH, Kim SH, et al:: Unexpected partial correction of metabolic and behavioral phenotypes of Alzheimer's APP/PSEN1 mice by gene targeting of diabetes/Alzheimer's-related Sorcs1. Acta Neuropathol Commun. 2016; 4(1): 16 PubMed Abstract | Publisher Full Text | Free Full Text

Kumagai AK, Vinores SA, Pardridge WM: Pathological upregulation of inner blood-retinal barrier Glut1 glucose transporter expression in diabetes mellitus. Brain Res. 1996; 706(2): 313-317.

PubMed Abstract | Publisher Full Text

Lane RF, Raines SM, Steele JW, et al: Diabetes-associated SorCS1 regulates Alzheimer's amyloid-beta metabolism: evidence for involvement of SorL1 and the retromer complex. J Neurosci. 2010; 30(39): 13110-13115.

PubMed Abstract | Publisher Full Text | Free Full Text

Lane RF, Steele JW, Cai D, et al.: Protein sorting motifs in the cytoplasmic tai of SorCS1 control generation of Alzheimer's amyloid- $\beta$ peptide. $J$ Neurosci. 2013; 33(16): 7099-7107.

PubMed Abstract | Publisher Full Text | Free Full Text

Le DS, Pannacciulli N, Chen K, et al.: Less activation of the left dorsolateral prefrontal cortex in response to a meal: a feature of obesity. Am J Clin Nutr. 2006; 84(4): 725-731.

PubMed Abstract

Li H, Kang Z, Qiu W, et al.: Hemoglobin A1C is independently associated with severity and prognosis of brainstem infarctions. J Neurol Sci. 2012; 317(1-2): 87-91.

PubMed Abstract | Publisher Full Text

Li L, Cheng WY, Glicksberg BS, et al:: Identification of type 2 diabetes subgroups through topological analysis of patient similarity. Sci Transl Med. 2015: 7(311): 311ra174.

PubMed Abstract | Publisher Full Text | Free Full Text

Linder K, Schleger F, Kiefer-Schmidt I, et al:: Gestational Diabetes Impairs Human Fetal Postprandial Brain Activity. J Clin Endocrinol Metab. 2015; 100(11): 4029-4036.

PubMed Abstract | Publisher Full Text

Liu S, Labouèbe G, Karunakaran S, et al.: Effect of insulin on excitatory synaptic transmission onto dopamine neurons of the ventral tegmental area in a mouse model of hyperinsulinemia. Nutr Diabetes. 2013; 3: e97.

PubMed Abstract | Publisher Full Text | Free Full Text

Macauley SL, Stanley M, Caesar EE, et al:: Hyperglycemia modulates extracellular amyloid- $\beta$ concentrations and neuronal activity in vivo. J Clin Invest. 2015; 125(6): 2463-7.

PubMed Abstract | Publisher Full Text | Free Full Text

MacQueen G, Frodl T: The hippocampus in major depression: evidence for the convergence of the bench and bedside in psychiatric research? Mol Psychiatry. 2011; 16(3): 252-264.

PubMed Abstract | Publisher Full Text

Malek-Ahmadi M, Beach T, Obradov A, et al:: Increased Alzheimer's disease neuropathology is associated with type 2 diabetes and ApoE $\varepsilon .4$ carrier status. Curr Alzheimer Res. 2013; 10(6): 654-659.

PubMed Abstract | Publisher Full Text | Free Full Text

Matsuzaki T, Sasaki K, Tanizaki Y, et al.: Insulin resistance is associated with the pathology of Alzheimer disease: the Hisayama study. Neurology. 2010 75(9): 764-770.

PubMed Abstract | Publisher Full Text

Mauras N, Mazaika P, Buckingham B, et al.: Longitudinal assessment of neuroanatomical and cognitive differences in young children with type 1 diabetes: association with hyperglycemia. Diabetes. 2015; 64(5): 1770-1779. PubMed Abstract | Publisher Full Text | Free Full Text

Mazaika PK, Weinzimer SA, Mauras N, et al:: Variations in Brain Volume and Growth in Young Children With Type 1 Diabetes. Diabetes. 2016; 65(2): 476-85. PubMed Abstract | Publisher Full Text | Free Full Text

McNay EC, Ong CT, McCrimmon RJ, et al.: Hippocampal memory processes are modulated by insulin and high-fat-induced insulin resistance. Neurobiol Learn Mem. 2010; 93(4): 546-553.

PubMed Abstract | Publisher Full Text | Free Full Text

Miller AA, Spencer SJ: Obesity and neuroinflammation: a pathway to cognitive impairment. Brain Behav Immun. 2014; 42: 10-21.

PubMed Abstract | Publisher Full Text

Montagne $\mathrm{A}, \mathrm{Pa} \mathrm{J}$, Zlokovic $\mathrm{BV}$ : Vascular plasticity and cognition during normal aging and dementia. JAMA Neurol. 2015; 72(5): 495-496.

PubMed Abstract | Publisher Full Text | Free Full Text

Moran C, Beare R, Phan TG, et al:: Type 2 diabetes mellitus and biomarkers of neurodegeneration. Neurology. 2015; 85(13): 1123-1130.

PubMed Abstract | Publisher Full Text 
Musen G, Simonson DC, Bolo NR, et al.: Regional brain activation during hypoglycemia in type 1 diabetes. J Clin Endocrinol Metab. 2008; 93(4): 1450-1457. PubMed Abstract | Publisher Full Text | Free Full Text

Nandipati S, Luo X, Schimming C, et al:: Cognition in non-demented diabetic older adults. Curr Aging Sci. 2012; 5(2): 131-135.

PubMed Abstract | Publisher Full Text | Free Full Text

Nelson PT, Smith CD, Abner EA, et al.: Human cerebral neuropathology of Type 2 diabetes mellitus. Biochim Biophys Acta. 2009; 1792(5): 454-469.

PubMed Abstract | Publisher Full Text | Free Full Text

Norton S, Matthews FE, Barnes DE, et al.: Potential for primary prevention of .

2014; 13(8): 788-794.

PubMed Abstract | Publisher Full Tex

Novak V, Milberg W, Hao Y, et al.: Enhancement of vasoreactivity and cognition by intranasal insulin in type 2 diabetes. Diabetes Care. 2014; 37(3): 751-759. PubMed Abstract | Publisher Full Text | Free Full Text

Nunley KA, Rosano C, Ryan CM, et al.: Clinically Relevant Cognitive Impairmen in Middle-Aged Adults With Childhood-Onset Type 1 Diabetes. Diabetes Care. 2015a; 38(9): 1768-1776.

PubMed Abstract | Publisher Full Text | Free Full Text

Nunley KA, Ryan CM, Orchard TJ, et al:: White matter hyperintensities in middleaged adults with childhood-onset type 1 diabetes. Neurology. 2015b; 84(20) 2062-2069.

PubMed Abstract | Publisher Full Text | Free Full Text

Oberman L, Pascual-Leone A: Changes in plasticity across the lifespan: cause of disease and target for intervention. Prog Brain Res. 2013; 207: 91-120. PubMed Abstract | Publisher Full Text | Free Full Text

Pannacciulli N, Del Parigi A, Chen K, et al.: Brain abnormalities in human obesity: a voxel-based morphometric study. Neuroimage. 2006; 31(4): 1419-1425. PubMed Abstract | Publisher Full Text

Pascual-Leone A, Freitas C, Oberman L, et al.: Characterizing brain cortical plasticity and network dynamics across the age-span in health and disease with TMS-EEG and TMS-fMRI. Brain Topogr. 2011; 24(3-4): 302-315.

PubMed Abstract | Publisher Full Text | Free Full Text

Peila R, Rodriguez BL, Launer LJ, et al:: Type 2 diabetes, APOE gene, and the risk for dementia and related pathologies: The Honolulu-Asia Aging Study. Diabetes. 2002: 51(4): 1256-1262.

PubMed Abstract | Publisher Full Text

Poldrack RA, Laumann TO, Koyejo O, et al.: Long-term neural and physiological phenotyping of a single human. Nat Commun. 2015; 6: 8885

PubMed Abstract | Publisher Full Text | Free Full Tex

Raber J: Detrimental effects of chronic hypothalamic-pituitary-adrenal axis activation. From obesity to memory deficits. Mol Neurobiol. 1998; 18(1): 1-22. PubMed Abstract | Publisher Full Tex

Raji CA, Ho AJ, Parikshak NN, et al.: Brain structure and obesity. Hum Brain Mapp. 2010; 31(3): 353-364

PubMed Abstract | Publisher Full Text | Free Full Text

Ramirez A, Wolfsgruber S, Lange $\mathrm{C}$, et al:: Elevated $\mathrm{HbA}$ is associated with increased risk of incident dementia in primary care patients. $J$ Alzheimers Dis. 2015; 44(4): 1203-1212.

PubMed Abstract | Publisher Full Tex

Rivera EJ, Goldin A, Fulmer N, et al: Insulin and insulin-like growth factor expression and function deteriorate with progression of Alzheimer's disease: link to brain reductions in acetylcholine. J Alzheimers Dis. 2005; 8(3): 247-268. PubMed Abstract

Rivera HM, Kievit P, Kirigiti MA, et al: Maternal high-fat diet and obesity impact palatable food intake and dopamine signaling in nonhuman primate offspring. Obesity (Silver Spring). 2015; 23(11): 2157-2164

PubMed Abstract | Publisher Full Text | Free Full Text

Roberts RO, Knopman DS, Cha RH, et al:: Diabetes and elevated hemoglobin A1c levels are associated with brain hypometabolism but not amyloid accumulation. J Nucl Med. 2014; 55(5): 759-764.

PubMed Abstract | Publisher Full Text | Free Full Text

Ruiz $\mathrm{HH}$, Chi T, Lindtner C, et al:: Increased susceptibility to metabolic dysregulation in a mouse model of Alzheimer's disease is associated with impaired hypothalamic insulin signaling and elevated BCAA levels. Alzheimers Dement. 2016; pii: S1552-5260(16)00049-2.

PubMed Abstract | Publisher Full Text

Ryan JP, Aizenstein HJ, Orchard TJ, et al: Age of Childhood Onset in Type 1 Diabetes and Functional Brain Connectivity in Midlife. Psychosom Med. 2015; 77(6): 622-630

PubMed Abstract | Publisher Full Text | Free Full Text

Sabia S, Kivimaki M, Shipley MJ, et al:: Body mass index over the adult life course and cognition in late midlife: the Whitehall II Cohort Study. Am J Clin Nutr. 2009; 89(2): 601-607.

PubMed Abstract | Publisher Full Text | Free Full Text

Schneider JA, Arvanitakis Z, Bang W, et al:: Mixed brain pathologies account fo most dementia cases in community-dwelling older persons. Neurology. 2007; 69(24): 2197-2204

PubMed Abstract | Publisher Full Text

Schubert M, Gautam D, Surjo D, et al: Role for neuronal insulin resistance in neurodegenerative diseases. Proc Natl Acad Sci U S A. 2004; 101(9): 3100-3105. PubMed Abstract | Publisher Full Text | Free Full Text

Sellbom KS, Gunstad J: Cognitive function and decline in obesity. J Alzheimers Dis. 2012; 30(Suppl 2): S89-S95.

PubMed Abstract | Publisher Full Text

Semenkovich K, Patel PP, Pollock AB, et al.: Academic abilities and glycaemic control in children and young people with Type 1 diabetes mellitus. Diabet Med. 2015.

PubMed Abstract | Publisher Full Text | Free Full Text

Sevgi M, Rigoux L, Kühn AB, et al:: An Obesity-Predisposing Variant of the FTO Gene Regulates D2R-Dependent Reward Learning. J Neurosci. 2015; 35(36): 12584-12592.

PubMed Abstract | Publisher Full Text

Sharkey RJ, Karama S, Dagher A: Overweight is not associated with cortica thickness alterations in children. Front Neurosci. 2015; 9: 24.

PubMed Abstract | Publisher Full Text | Free Full Text

Shimizu F, Sano Y, Tominaga O, et al:: Advanced glycation end-products disrupt the blood-brain barrier by stimulating the release of transforming growth factor- $\beta$ by pericytes and vascular endothelial growth factor and matrix metalloproteinase-2 by endothelial cells in vitro. Neurobiol Aging. 2013; 34(7): 1902-1912.

PubMed Abstract | Publisher Full Text

Small DM, Zatorre RJ, Jones-Gotman M: Increased intensity perception of aversive taste following right anteromedial temporal lobe removal in humans. Brain 2001: 124(Pt 8): 1566-1575.

PubMed Abstract | Publisher Full Text

Snyder HM, Corriveau RA, Craft S, et al:: Vascular contributions to cognitive impairment and dementia including Alzheimer's disease. Alzheimers Dement. 2015; 11(6): 710-717.

PubMed Abstract | Publisher Full Text | Free Full Text

Sonnen JA, Larson EB, Brickell K, et al.: Different patterns of cerebral injury in dementia with or without diabetes. Arch Neurol. 2009; 66(3): 315-322.

PubMed Abstract | Publisher Full Text | Free Full Text

Sperling RA, Amariglio RE, Marshall GA, et al:: Establishing Clinical Relevance in Preclinical Alzheimer's Disease. J Prev Alzheimers Dis. 2015; 2(2):

$85-87$.

PubMed Abstract | Publisher Full Text | Free Full Text

Steculorum SM, Solas M, Brüning JC: The paradox of neuronal insulin action and resistance in the development of aging-associated diseases. Alzheimers Dement. 2014; 10(1 Suppl): S3-11.

PubMed Abstract | Publisher Full Text

Stice E, Spoor S, Bohon C, et al:: Relation between obesity and blunted striatal response to food is moderated by TaqIA A1 allele. Science. 2008; 322(5900): 449-452.

PubMed Abstract | Publisher Full Text | Free Full Text

Stouffer MA, Woods CA, Patel JC, et al.: Insulin enhances striatal dopamine release by activating cholinergic interneurons and thereby signals reward. Nat Commun. 2015; 6: 8543.

PubMed Abstract | Publisher Full Text | Free Full Text

Stranahan AM, Arumugam TV, Cutler RG, et al.: Diabetes impairs hippocampal function through glucocorticoid-mediated effects on new and mature neurons. Nat Neurosci. 2008; 11(3): 309-317.

PubMed Abstract | Publisher Full Text | Free Full Text

Sun X, Kroemer NB, Veldhuizen MG, et al.: Basolateral amygdala response to food cues in the absence of hunger is associated with weight gain susceptibility. J Neurosci. 2015; 35(20): 7964-7976.

PubMed Abstract | Publisher Full Text | Free Full Text

Suzuki R, Ferris HA, Chee MJ, et al:: Reduction of the Cholesterol Sensor SCAP in the Brains of Mice Causes Impaired Synaptic Transmission and Altered Cognitive Function. PLoS Biol. 2013; 11(4): e1001532. PubMed Abstract | Publisher Full Text | Free Full Text

Suzuki R, Lee K, Jing E, et al.: Diabetes and insulin in regulation of brain cholesterol metabolism. Cell Metab. 2010; 12(6): 567-579.

PubMed Abstract | Publisher Full Text | Free Full Text

Sweetnam D, Holmes A, Tennant KA, et al.: Diabetes impairs cortical plasticity and functional recovery following ischemic stroke. J Neurosci. 2012; 32(15): 5132-5143

PubMed Abstract | Publisher Full Text

Talbot $\mathrm{K}$, Wang $\mathrm{HY}$ Kazi $\mathrm{H}$, et al: Demonstrated brain insulin resistance in Alzheimer's disease patients is associated with IGF-1 resistance, IRS-1 dysregulation, and cognitive decline. J Clin Invest. 2012; 122(4): 1316-1338. PubMed Abstract | Publisher Full Text | Free Full Text

Thaler JP, Schwartz MW: Minireview: Inflammation and obesity pathogenesis: the hypothalamus heats up. Endocrinology. 2010; 151(9): 4109-4115. PubMed Abstract | Publisher Full Text | Free Full Text

Thompson PM, Stein JL, Medland SE, et al:: The ENIGMA Consortium: large-scale collaborative analyses of neuroimaging and genetic data. Brain Imaging Behav. 2014; 8(2): 153-182.

PubMed Abstract | Publisher Full Text | Free Full Text

Trollor JN, Smith E, Agars E, et al:: The association between systemic inflammation and cognitive performance in the elderly: the Sydney Memory 
and Ageing Study. Age (Dordr). 2012; 34(5): 1295-1308. PubMed Abstract | Publisher Full Text | Free Full Text

Vainik U, Dagher A, Dubé L, et al.: Neurobehavioural correlates of body mass index and eating behaviours in adults: a systematic review. Neurosci Biobehav Rev. 2013; 37(3): 279-299.

PubMed Abstract | Publisher Full Text | Free Full Text

Val-Laillet $\mathrm{D}$, Layec $\mathrm{S}$, Guérin $\mathrm{S}$, et al:: Changes in brain activity after a

diet-induced obesity. Obesity (Silver Spring). 2011; 19(4): 749-756.

PubMed Abstract | Publisher Full Text

Vogt MC, Paeger L, Hess S, et al.: Neonatal insulin action impairs hypothalamic neurocircuit formation in response to maternal high-fat feeding. Cell. 2014;

156(3): 495-509.

PubMed Abstract | Publisher Full Text | Free Full Text

Wang D, Buckner RL, Fox MD, et al:: Parcellating cortical functional networks in individuals. Nat Neurosci. 2015; 18(12): 1853-1860.

PubMed Abstract | Publisher Full Text | Free Full Text

Watson GS, Cholerton BA, Reger MA, et al:: Preserved cognition in patients

with early Alzheimer disease and amnestic mild cognitive impairment during treatment with rosiglitazone: a preliminary study. Am J Geriatr Psychiatry. 2005 13(11): 950-958.

PubMed Abstract | Publisher Full Text

Wosiski-Kuhn M, Erion JR, Gomez-Sanchez EP, et al.: Glucocorticoid receptor activation impairs hippocampal plasticity by suppressing BDNF expression in obese mice. Psychoneuroendocrinology. 2014; 42: 165-177.

PubMed Abstract | Publisher Full Text | Free Full Text
Yaffe K, Lindquist K, Schwartz AV, et al:: Advanced glycation end product level, diabetes, and accelerated cognitive aging. Neurology. 2011; 77(14):

1351-1356.

PubMed Abstract | Publisher Full Text | Free Full Text

Yaffe K: Metabolic syndrome and cognitive disorders: is the sum greater than ts parts? Alzheimer Dis Assoc Disord. 2007; 21(2): 167-171.

PubMed Abstract | Publisher Full Text

Yarchoan M, Arnold SE: Repurposing diabetes drugs for brain insulin resistance in Alzheimer disease. Diabetes. 2014; 63(7): 2253-2261.

PubMed Abstract | Publisher Full Text | Free Full Text

Yarchoan M, Toledo JB, Lee EB, et al:: Abnormal serine phosphorylation of insulin receptor substrate 1 is associated with tau pathology in Alzheimer's disease and tauopathies. Acta Neuropathol. 2014; 128(5): 679-689. PubMed Abstract | Publisher Full Text | Free Full Text

Yau PL, Castro MG, Tagani A, et al:: Obesity and metabolic syndrome and functional and structural brain impairments in adolescence. Pediatrics. 2012; 130(4): e856-e864.

PubMed Abstract | Publisher Full Text | Free Full Text

Yau PL, Kang EH, Javier DC, et al:: Preliminary evidence of cognitive and brain abnormalities in uncomplicated adolescent obesity. Obesity (Silver Spring). 2014; 22(8): 1865-1871.

PubMed Abstract | Publisher Full Text | Free Full Text

Yeo BT, Krienen FM, Eickhoff SB, et al.: Functional Specialization and Flexibility in Human Association Cortex. Cereb Cortex. 2016; 26(1): 465.

PubMed Abstract | Publisher Full Text | Free Full Tex 


\title{
Open Peer Review
}

\section{Current Peer Review Status:}

\section{Version 1}

Reviewer Report 06 May 2016

https://doi.org/10.5256/f1000research.8926.r13698

(c) 2016 Azarpazhooh $M$ et al. This is an open access peer review report distributed under the terms of the Creative Commons Attribution License, which permits unrestricted use, distribution, and reproduction in any medium, provided the original work is properly cited.

\author{
Mahmoud Reza Azarpazhooh \\ ${ }^{1}$ Department of Clinical Neurological Sciences, University of Western Ontario, London, ON, \\ Canada \\ 2 Department of Neurology, Mashhad University of Medical Sciences, Mashhad, Iran \\ Vladimir Hachinski \\ Department of Clinical Neurological Sciences (CNS), University of Western Ontario, London, ON, \\ Canada
}

The authors offer a balanced review regarding the relationship between cognitive decline and insulin resistance. They cover a majority of important studies, providing excellent insights into our current knowledge, and more importantly gaps in definition, pathophysiology, and prevention and treatment of cognitive impairment related to diabetes.

One of the strongest parts of the paper is highlighting a probable reciprocal cause and effect relation between diabetes, leading to the cognitive decline, and neurodegenerative lesions in the brain, resulting in central insulin resistance. On the one hand, diabetes can contribute to dementia via a range of mechanisms, including vascular components ${ }^{1}$, peripheral and central inflammatory response via activation of microglia ${ }^{2}$, change in the blood brain barrier ${ }^{3}$, and neurostructural changes, both in white and gray matter ${ }^{4}$. On the other hand, neurodegenerative changes, such as amyloid deposition in the brain, especially in the hypothalamus ${ }^{5}$, may lead to insulin resistance and probably a central type of metabolic disorders and diabetes. This idea opens a new window in organized research for dementia and diabetes and at the same time underlines an urgent need to clarify the priorities in these vital fields.

This paper provides a long list of possible gaps and plans for further studies; however, some themes stand out:

1. An urgent need for definitions, and collaborations: Despite a relatively high incidence of diabetes and dementia and not surprisingly extensive research in these conditions, still no worldwide consensus exists on definitions, inclusion and exclusion criteria and clarity on some key words. This can be partially explained by focused research in diabetes and dementia, conducted in different disciplines in parallel and sometimes opposite directions. 
Considering diabetes as a systemic disease, affecting almost each and every part of human body, and cognitive decline, as a condition with a wide range of etiologies, and presentations, it is a high time to look at these common disorders in a more holistic, multidimensional vision and create data banks, including all available data and use similar definitions, and common vocabularies. Such national/international data banks may provide a better insight into epidemiology, pathophysiology, prevention, and treatment of dementia and diabetes and at the same time can save our limited health resources.

2. Experimental studies: Animal studies play a significant role on our current knowledge in medicine. Despite their undeniable advantages in the evaluation of pathogenesis and treatment of several diseases, they still suffer from specific limitations, mainly due to high costs as well as the selection of the most appropriate animals. A similar significant gap can also be seen in animal studies of dementia and diabetes, using different animals, with limited sample sizes and lack of enough controls. Therefore, it may be worthwhile creating national/ international data banks for animal samples from both sexes with or without diseases, covering all possible aspects of animal studies, from behavioral and cognitive abilities to imaging and pathology. Such data banks could facilitate multidiscipline studies, save our resources and more importantly save on the number of sacrifized animals. This is an important step towards a better understanding of the pathogenesis of dementia and diabetes, and even starting new trials based on the underlying causes, such as antiinflammatory medications.

3. Human studies: Using a common vocabulary in definition and categorization of diabetes and dementia, having national / international animal banks and finally a multidimensional approach toward such diseases with multiple and reciprocal presentations and etiologies may lead to optimal human studies and the creation of national/international human data banks. Undoubtedly, we need to provide more sensitive and specific instruments as well as tests to assess diabetes in the first stages and at the same time evaluate a range of cognitive abilities from executive functions, which is more common in vascular cognitive impairment, to memory abilities. In addition, such holistic vision can identify a range of comorbid and confounding disabilities in diabetes, from obesity and vascular diseases to important psychiatric conditions, such as depression. Finally, there is a need for designing multidiscipline studies to assess epidemiological aspects of dementia and diabetes, public health impact and practical clinical trials. Such studies can provide a great chance to detect diseases in pre-symptomatic phases and follow them longitudinally. Multicenter trials with factorial design, using a combination of lifestyle modifications and medical intervention to diagnose as well as prevent/ treat diabetes and dementia would have paramount of importance in each and every community worldwide.

In summary, Stoeckel and colleagues highlight a significant gap of knowledge and consequently appropriate management, definitions, pathogenesis and treatment of dementia and diabetes. A combination of several comorbid and confounding factors and the same time a possible bidirectional relationship between these common conditions emphasizes an urgent need for a more holistic multidimensional vision to tackle diabetes and dementia together.

\section{References}

1. Gorelick PB, Scuteri A, Black SE, Decarli C, et al.: Vascular contributions to cognitive impairment and dementia: a statement for healthcare professionals from the american heart association/american stroke association.Stroke. 2011; 42 (9): 2672-713 PubMed Abstract | 


\section{Publisher Full Text}

2. Dey A, Hao S, Erion JR, Wosiski-Kuhn M, et al.: Glucocorticoid sensitization of microglia in a genetic mouse model of obesity and diabetes.J Neuroimmunol. 2014; 269 (1-2): 20-7 PubMed Abstract | Publisher Full Text

3. Shimizu F, Sano Y, Tominaga O, Maeda T, et al.: Advanced glycation end-products disrupt the blood-brain barrier by stimulating the release of transforming growth factor- $\beta$ by pericytes and vascular endothelial growth factor and matrix metalloproteinase- 2 by endothelial cells in vitro. Neurobiol Aging. 2013; 34 (7): 1902-12 PubMed Abstract | Publisher Full Text

4. Reijmer YD, Brundel M, de Bresser J, Kappelle LJ, et al.: Microstructural white matter abnormalities and cognitive functioning in type 2 diabetes: a diffusion tensor imaging study. Diabetes Care. 2013; 36 (1): 137-44 PubMed Abstract | Publisher Full Text

5. Ishii M, Iadecola C: Metabolic and Non-Cognitive Manifestations of Alzheimer's Disease: The Hypothalamus as Both Culprit and Target of Pathology.Cell Metab. 2015; 22 (5): 761-76 PubMed Abstract | Publisher Full Text

Competing Interests: No competing interests were disclosed.

We confirm that we have read this submission and believe that we have an appropriate level of expertise to confirm that it is of an acceptable scientific standard.

Author Response 02 Jun 2016

Luke Stoeckel, National Institutes of Health, Bethesda, USA

Referee Reports: 6 May 2016 (MR Azarpazhooh and V Hachinski):

We thank the referees for highlighting important strengths of our manuscript: "The authors offer a balanced review regarding the relationship between cognitive decline and insulin resistance. They cover a majority of important studies, providing excellent insights into our current knowledge, and more importantly gaps in definition, pathophysiology, and prevention and treatment of cognitive impairment related to diabetes.

One of the strongest parts of the paper is highlighting a probable reciprocal cause and effect relation between diabetes, leading to the cognitive decline, and neurodegenerative lesions in the brain, resulting in central insulin resistance...."

Response: We agree with the sentiments expressed by these referees and have expanded the text to further emphasize the major themes identified at the workshop and identified by these referees, and we expanded discussion of these themes to better guide future research in this area (see pgs. 8-9). We request that the list of other research needs be moved to the supplementary materials section.

Competing Interests: No competing interests were disclosed. 
(c) 2016 Barger S. This is an open access peer review report distributed under the terms of the Creative Commons Attribution License, which permits unrestricted use, distribution, and reproduction in any medium, provided the original work is properly cited.

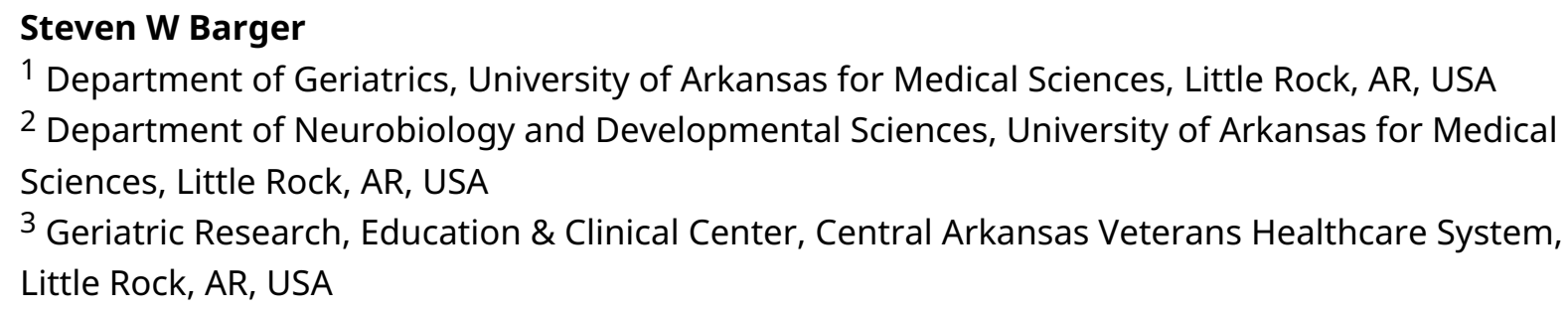

This rather comprehensive review of the connections between the metabolic syndrome associated with Type-2 diabetes mellitus (T2DM) and cognitive impairment was inspired by a workshop held by the National Institute of Diabetes and Digestive and Kidney Diseases (NIDDK). The article is so thorough and well organized that one assumes the proceedings of that meeting must have been only the starting point and that the thoughts and opinions arising from that brainstorming session have been embellished with considerable diligence and reflection here.

Most of the points covered in this "white paper" are well reasoned and well researched. And all the topics represent elements of pathology and pathogenesis that will be key to any faithful attempt to understand the intersection between T2DM, dementia, and milder forms of cognitive impairment. Other authors have often succumbed to the temptation to focus on Alzheimer's disease (AD) as the tag-word for these discussions, but one of the triumphs of this review is its more general consideration of dementia and sub-demented deficiencies as per their connections to energy substrates, both in the central nervous system and peripherally. Indeed, the authors highlight a consideration that seems to be gaining in prominence and frequency in discussions of $A D$ itself: the fact that heterogeneity-especially within certain classifications of age, gender, and genetics-suggests not only multiple routes to $A D$, but also multiple disease endpoints. Particularly within the "oldest-old" populations, APOE4-negative individuals, and high-risk populations such as military veterans, classic AD pathology correlates rather loosely with cognition. To their credit, the authors discuss the possibility that metabolic derangement may yet be shown to be the driving force for at least some of these cases:

"II]t is still unclear if the relationship between diabetes and neurocognitive dysfunction and dementia is due to classic $A D$ pathology, vascular processes such as infarcts or vessel pathology, other pathologies less closely related to $A D$ or vascular disease (e.g., impaired brain insulin signaling), or some combination of these. Some have proposed that 'all-cause' dementia be employed in order to avoid the implication that we can classify etiologies accurately based on current knowledge."

Another important point made here regards the direction of causality. Hypotheses inspired by the earliest epidemiological links between dementia and T2DM presumed that complications of the latter drive the neuropathologies (mostly, those related to protein aggregation) that underlie AD and related dementias. But a more accurate picture of the relevant events in AD progression has been afforded-largely through advances in neuroimaging tools-and this insight sets the stage for researchers to now say,

\section{"...the pathophysiological processes that lead to metabolic and neurocognitive dysfunction precede the}


development of clinical syndromes by years.... Indeed, AD neuropathology is detectable more than 10 years before the onset of the first clinical symptoms (Bateman et al., 2012) and pre-diabetes also precedes diabetes by years in most cases."

In fact, data indicate that changes in amyloid $\beta$-peptide $(A \beta)$ precede reductions in cerebral glucose utilization, the latter of which may be an important index of metabolic syndrome (below). Supported by evidence from animal models, emerging trends in hypothesis-building include the supposition that CNS accumulation of $A \beta$, and perhaps other elements of neurodegeneration, are sufficient to perturb peripheral metabolism. This allows consideration of the possibility that correlations between cognitive impairment and cortical amyloid burden are so capricious because an important modulatory (or even instigating) factor is the accumulation of $A \beta$ in subcortical regions:

"Therefore, it is plausible that AD pathology (amyloid-beta or $A \beta$, tauopathy) may be present in the hypothalamus prior to the onset of cognitive symptoms, and that this hypothalamic pathology could disrupt homeostatic functions such as energy balance and peripheral metabolism prior to the onset of detectable cognitive dysfunction (Ishii \& Iadecola, 2015b)."

It is also encouraging to see the inclusion of information on effects of obesity and diet that appear to be independent of glycemic regulation. This is an intriguing body of data, considering the untoward effects of high-fat diets in rodents vis-à-vis the benefits that ketogenic diets and their mimics seem to have in humans ${ }^{1}$. It seems that metabolic impacts on brain health could benefit from better understanding of the effects that are brought to bear by shifts between the prominent energy-substrate molecules, perhaps through impacts on such substances that also impact neurotransmitter pools, such as glutamate and glutamine. And it might be productive here to consider hypotheses regarding the finding that obesity in midlife is correlated with dementia manifest decades later ${ }^{2}$, at a time when weight loss may be more common.

For all the salient points made in this white paper, the authors still find themselves perpetuating a conventional assumption that seems shortsighted in light of a substantial body of evidence; this is all the more disappointing because they consider what the implications would be "if metabolic disease impacts the brain in ways that differ from its effects on other end organs impacted by diabetes and other metabolic disease." This is almost certainly the case. The traditional view that elevated glucose in the blood must, by necessity, produce elevated glucose in the brain ignores the existence of the blood-brain barrier (BBB); very little glucose can enter the cerebrum, or most other regions of the CNS, without regulated transport, the bulk of which is handled by glucose transporter 1 (GLUT1). Thus, it was quite surprising to read a major conclusion in the paper that seems to have been based primarily on a single publication, and moreover, one devoted not to the brain but to the retina:

"Diabetes is associated with upregulation of the GLUT1 glucose transporter (Kumagai et al., 1996); glucose provides the original source of glutamate in the brain (Bradford \& Thomas, 1969), and chronic hyperglycemia may thus lead to excessive glutamate and increased risk of excitotoxicity."

This is subject to criticism on two counts: 1) Several studies show that AD and hyperglycemia are both associated with reductions in endothelial glucose transporters, likely reflecting - at least in the latter-a reactive feedback inhibition; this probably contributes to the diminished 2deoxyglucose accumulation in both disorders. 2) Excitotoxicity is more likely to be a consequence 
of glucose deprivation; this is a well-established relationship 3,4 , whereas the claim that high glucose elevates glutamate release is tenuous and unsupported by citations. Publications documenting a diminution of GLUT1 levels in hyperglycemia and/or the converse, an elevation in hypoglycemia, comprise an overwhelming body of evidence ${ }^{5-10}$. The authors later provide some evidence suggesting effects on the BBB from metabolic abnormalities in rat models, particularly those brought on by diet, but data in humans is spotty and of unclear relevance to glucose delivery.

Less serious or less consequential issues arose with regard to a few other elements in the paper:

"Unlike other complications of diabetes..., neurocognitive complications of diabetes have not clearly been demonstrated to correlate with measures of peripheral glycemia (with the exception of very poor glycemic control, HbA1c > 10\% and a potential role for glycemic variability) and there is only limited evidence for a modest association with other measures of peripheral glucose regulation...."

Why would it be necessary-or indeed, even helpful-to exclude HbA1c levels and glycemic control from the calculus? Which indices of peripheral glycemia would be more justifiable? To be sure, $10 \%$ is a quite high level for $\mathrm{HbA1c}$, but lower levels might show a detectable effect in an adequately powered study. Moreover, HbA1c might not change dramatically under conditions of highly fluctuating blood-glucose concentrations, and yet such wild swings could easily produce intolerable strains on glucose-sensitive tissues-including brain endothelium-simply by virtue of their volatility.

The authors are to be applauded for their mention (however brief) of the apparent paradox between the ill effects of pathological insulin resistance versus the benefits of experimentally interrupting insulin signaling, at least in C. elegans. It should be noted that similar benefits (e.g., on live span) accrue in mammals from inhibition of signaling for insulin-like growth factor (IGF), and C. elegans have only one peptide to accomplish the roles of both insulin and IGF. Nevertheless, the conundrum is one that has vexed experimental gerontologists for decades, owing in part to the similar benefits afforded by attention of the insulin/IGF signaling (IIS) pathway and by dietary restriction, the latter of which certainly reduces overall insulin production. One should not expect the authors to have cracked this tough nut, but important rumination might result from a slightly more complete discussion of the differences between reactive (feedbackmediated) insulin resistance and the proactive sort effected by empirical manipulation of IIS.

Also given short shrift here is the undeniable connection of inflammation to both metabolic syndrome and neurocognitive disorders. This is obviously an underappreciated link that deserves greater attention among scientists seeking to synthesize these fields; reviewers of grants and papers continue to express befuddlement when the topic of neuroinflammation is broached in this context. Given the overwhelming evidence for inflammation-related events in the etiologies of both T2DM and AD, it is almost certain to contribute to their coincidence. In fact, compelling evidence has supported just this sort of causal involvement in animal models ${ }^{11}$. The authors have included the word "inflammation," distributed diffusely in the paper; perhaps it would create the appropriate emphasis if some of these references were consolidated in one or two paragraphs along with more specific information, e.g., the seminal role of IKK2 in insulin resistance ${ }^{12}$ and $A \beta$ effects ${ }^{13}$.

Finally, the paper's conclusion with "Some broad research needs" is doubtlessly faithful to the 
output of the workshop's deliberations, but many of the points outlined in this list come across as rather vague. Without further elaboration, it is not clear what gaps in knowledge some of them would address. One wonders if several could be combined and embellished with a bit more elaboration.

In its overall contribution, this white paper provides a very useful and much-needed synthesis of data and concepts regarding the connections between cognition and metabolic derangement. Modifiable elements of lifestyle and environment have recently emerged as major considerations in the prevention of dementia. Stoeckel et al. have enhanced the conversation by broadening it to other categories of cognitive impairment. In addition, they largely succeeded in summarizing the current state of fields that can seem disparate, and they highlight opportunities to draw these fields closer.

\section{References}

1. Reger MA, Henderson ST, Hale C, Cholerton B, et al.: Effects of beta-hydroxybutyrate on cognition in memory-impaired adults.Neurobiol Aging. 2004; 25 (3): 311-4 PubMed Abstract | Publisher Full Text

2. Anstey KJ, Cherbuin N, Budge M, Young J: Body mass index in midlife and late-life as a risk factor for dementia: a meta-analysis of prospective studies.Obes Rev. 2011; 12 (5): e426-37 PubMed Abstract | Publisher Full Text

3. Monyer H, Goldberg MP, Choi DW: Glucose deprivation neuronal injury in cortical culture.Brain Res. 1989; 483 (2): 347-54 PubMed Abstract

4. Singh SP, Ehmann S, Snyder AK: Ethanol and glucose-deprivation neurotoxicity in cortical cell cultures.Metabolism. 1994; 43 (9): 1108-13 PubMed Abstract

5. Gjedde A, Crone C: Blood-brain glucose transfer: repression in chronic hyperglycemia.Science. 1981; 214 (4519): 456-7 PubMed Abstract

6. McCall AL, Millington WR, Wurtman RJ: Metabolic fuel and amino acid transport into the brain in experimental diabetes mellitus.Proc Natl Acad Sci U S A. 1982; 79 (17): 5406-10 PubMed Abstract 7. Matthaei $S$, Horuk R, Olefsky JM: Blood-brain glucose transfer in diabetes mellitus. Decreased number of glucose transporters at blood-brain barrier.Diabetes. 1986; 35 (10): 1181-4 PubMed Abstract

8. Pardridge WM, Triguero D, Farrell CR: Downregulation of blood-brain barrier glucose transporter in experimental diabetes.Diabetes. 1990; 39 (9): 1040-4 PubMed Abstract 9. Lutz AJ, Pardridge WM: Insulin therapy normalizes GLUT1 glucose transporter mRNA but not immunoreactive transporter protein in streptozocin-diabetic rats.Metabolism. 1993; 42 (8): 939-44 PubMed Abstract

10. Cornford EM, Hyman S, Cornford ME, Clare-Salzler M: Down-regulation of blood-brain glucose transport in the hyperglycemic nonobese diabetic mouse.Neurochem Res. 1995; 20 (7): 869-73 PubMed Abstract

11. Clarke JR, Lyra E Silva NM, Figueiredo CP, Frozza RL, et al.: Alzheimer-associated A $\beta$ oligomers impact the central nervous system to induce peripheral metabolic deregulation.EMBO Mol Med. 2015; 7 (2): 190-210 PubMed Abstract | Publisher Full Text

12. Tanti JF, Jager J: Cellular mechanisms of insulin resistance: role of stress-regulated serine kinases and insulin receptor substrates (IRS) serine phosphorylation.Curr Opin Pharmacol. 2009; 9 (6): 753-62 PubMed Abstract | Publisher Full Text

13. Liu Y, Liu X, Hao W, Decker Y, et al.: IKK $\beta$ deficiency in myeloid cells ameliorates Alzheimer's disease-related symptoms and pathology.J Neurosci. 2014; 34 (39): 12982-99 PubMed Abstract I Publisher Full Text 
Competing Interests: No competing interests were disclosed.

\section{I confirm that I have read this submission and believe that I have an appropriate level of expertise to confirm that it is of an acceptable scientific standard, however I have significant reservations, as outlined above.}

\section{Author Response 02 Jun 2016}

Luke Stoeckel, National Institutes of Health, Bethesda, USA

Referee Reports: 12 April 2016 (SW Barger):

We appreciate that Dr. Barger felt this review was "so thorough and well organized that one assumes the proceedings of that meeting must have been only the starting point and that the thoughts and opinions arising from that brainstorming session have been embellished with considerable diligence and reflection here." We also thank the referee for concluding that "In its overall contribution, this white paper provides a very useful and much-needed synthesis of data and concepts regarding the connections between cognition and metabolic derangement. Modifiable elements of lifestyle and environment have recently emerged as major considerations in the prevention of dementia. Stoeckel et al. have enhanced the conversation by broadening it to other categories of cognitive impairment. In addition, they largely succeeded in summarizing the current state of fields that can seem disparate, and they highlight opportunities to draw these fields close".

Point 1: "It is also encouraging to see the inclusion of information on effects of obesity and diet that appear to be independent of glycemic regulation. This is an intriguing body of data, considering the untoward effects of high-fat diets in rodents vis-à-vis the benefits that ketogenic diets and their mimics seem to have in humans ${ }^{1}$. It seems that metabolic impacts on brain health could benefit from better understanding of the effects that are brought to bear by shifts between the prominent energy-substrate molecules, perhaps through impacts on such substances that also impact neurotransmitter pools, such as glutamate and glutamine. And it might be productive here to consider hypotheses regarding the finding that obesity in midlife is correlated with dementia manifest decades later ${ }^{2}$, at a time when weight loss may be more common."

Response: Text modified to make this important point clear (see p. 6, paragraph 1). "Compared to adults with normal body mass index (BMI = 18.5 - 24.9), overweight and obese adults in midlife (ages 40-59 years) have a relative risk (RR) of 1.35 (overweight) and 2.04 (obese) for $A D$ and 1.26 (overweight) and 1.64 (obese) of any cause dementia (Anstey et al. 2011). This association between overweight and obesity is not observed in late life (ages 60 years or older) at a time when weight loss is more common and a risk factor for dementia (Anstey et al. 2011)."

Point 2: "For all the salient points made in this white paper, the authors still find themselves perpetuating a conventional assumption that seems shortsighted in light of a substantial body of evidence; this is all the more disappointing because they consider what the implications would be "if metabolic disease impacts the brain in ways that differ from its 
effects on other end organs impacted by diabetes and other metabolic disease." This is almost certainly the case. The traditional view that elevated glucose in the blood must, by necessity, produce elevated glucose in the brain ignores the existence of the blood-brain barrier (BBB); very little glucose can enter the cerebrum, or most other regions of the CNS, without regulated transport, the bulk of which is handled by glucose transporter 1 (GLUT1). Thus, it was quite surprising to read a major conclusion in the paper that seems to have been based primarily on a single publication, and moreover, one devoted not to the brain but to the retina:

"Diabetes is associated with upregulation of the GLUT1 glucose transporter (Kumagai et al., 1996); glucose provides the original source of glutamate in the brain (Bradford \& Thomas, 1969), and chronic hyperglycemia may thus lead to excessive glutamate and increased risk of excitotoxicity."

This is subject to criticism on two counts: 1) Several studies show that AD and hyperglycemia are both associated with reductions in endothelial glucose transporters, likely reflecting - at least in the latter-a reactive feedback inhibition; this probably contributes to the diminished 2-deoxyglucose accumulation in both disorders. 2) Excitotoxicity is more likely to be a consequence of glucose deprivation; this is a well-established relationship 3,4, whereas the claim that high glucose elevates glutamate release is tenuous and unsupported by citations. Publications documenting a diminution of GLUT1 levels in hyperglycemia and/or the converse, an elevation in hypoglycemia, comprise an overwhelming body of evidence ${ }^{5-10}$. The authors later provide some evidence suggesting effects on the BBB from metabolic abnormalities in rat models, particularly those brought on by diet, but data in humans is spotty and of unclear relevance to glucose delivery."

Response: We agree with the reviewer and have reorganized the section on "Mechanisms linking diabetes to dementia (p. 3)" and have modified discussion of the relationship between peripheral hyperglycemia and CNS hyperglycemia, GLUT1 glucose transporter, and excitotoxicity in response to the reviewer's feedback. Specifically, we have indicated that excitotoxicity in the brain may be more closely related to glucose deprivation via reductions in endothelial glucose transporters.

The following text can be found on p. 4, paragraph 3: "Chronic hyperglycemia has been associated with reductions in endothelial glucose transporters such as GLUT1 that could lead to glucose deprivation and excitotoxicity, and could account for some of the neurocognitive complications of diabetes (Gjedde and Crone 1981; Matthaei et al. 1986). This is unlike diabetic retinopathy, which has been associated with upregulation of GLUT1 glucose transporter ( Kumagai et al., 1996) and is another example of how diabetic complications in the brain may differ from other organ systems."

Point 3: "Unlike other complications of diabetes..., neurocognitive complications of diabetes have not clearly been demonstrated to correlate with measures of peripheral glycemia (with the exception of very poor glycemic control, $\mathrm{HbA1c}>10 \%$ and a potential role for glycemic variability) and there is only limited evidence for a modest association with other measures of peripheral glucose regulation...."

"Why would it be necessary—or indeed, even helpful—to exclude HbA1c levels and glycemic 
control from the calculus? Which indices of peripheral glycemia would be more justifiable? To be sure, $10 \%$ is a quite high level for $\mathrm{HbA1c}$, but lower levels might show a detectable effect in an adequately powered study. Moreover, HbA1c might not change dramatically under conditions of highly fluctuating blood-glucose concentrations, and yet such wild swings could easily produce intolerable strains on glucose-sensitive tissues-including brain endothelium—simply by virtue of their volatility."

Response: We appreciate the need for clarification on this comment. We did not intend to suggest that $\mathrm{HbA} 1 \mathrm{c}$ or glycemic variability were unimportant, and we agree that some existing studies may be underpowered to detect effects at lower levels of hyperglycemia (i.e., $\mathrm{HbA} 1 \mathrm{c}<10 \%)$. We have modified our text to emphasize future studies should not ignore the roles of $\mathrm{HbA} 1 \mathrm{c}$ and glycemic variability, and there is a need for more adequately powered studies to clarify the roles for these variables in cognitive impairment and dementia. The following text can be found on p. 5, paragraph 2: "It is possible that lower levels of hyperglycemia (i.e., $\mathrm{HbA1c}<10 \%$ ) may have detectable effects on neurocognitive function in adequately powered studies or that $\mathrm{HbA1c}$ levels may not reflect highly fluctuating blood glucose concentrations, which could have independent deleterious effects on glucose-sensitive tissues such as brain endothelium."

Point 4: "The authors are to be applauded for their mention (however brief) of the apparent paradox between the ill effects of pathological insulin resistance versus the benefits of experimentally interrupting insulin signaling, at least in C. elegans. It should be noted that similar benefits (e.g., on live span) accrue in mammals from inhibition of signaling for insulin-like growth factor (IGF), and C. elegans have only one peptide to accomplish the roles of both insulin and IGF. Nevertheless, the conundrum is one that has vexed experimental gerontologists for decades, owing in part to the similar benefits afforded by attention of the insulin/IGF signaling (IIS) pathway and by dietary restriction, the latter of which certainly reduces overall insulin production. One should not expect the authors to have cracked this tough nut, but important rumination might result from a slightly more complete discussion of the differences between reactive (feedback-mediated) insulin resistance and the proactive sort effected by empirical manipulation of IIS."

Response: We appreciate this important point from the reviewer; however, this did not need receive substantial discussion at the workshop and, given the complexity of this issue, would require substantial more attention beyond the scope of the current paper. We have acknowledged this point in the manuscript. The following text can be found on p.5, paragraph 2: "The apparent paradox between pathological insulin resistance and the benefits of acute disruption of insulin signaling is a complex topic requiring further research attention."

Point 5: "Also given short shrift here is the undeniable connection of inflammation to both metabolic syndrome and neurocognitive disorders. This is obviously an underappreciated link that deserves greater attention among scientists seeking to synthesize these fields; reviewers of grants and papers continue to express befuddlement when the topic of neuroinflammation is broached in this context. Given the overwhelming evidence for inflammation-related events in the etiologies of both T2DM and AD, it is almost certain to contribute to their coincidence. In fact, compelling evidence has supported just this sort of 
causal involvement in animal models ${ }^{11}$. The authors have included the word "inflammation," distributed diffusely in the paper; perhaps it would create the appropriate emphasis if some of these references were consolidated in one or two paragraphs along with more specific information, e.g., the seminal role of IKK2 in insulin resistance ${ }^{12}$ and A $\beta$ effects ${ }^{13} . "$

Response: We agree with the reviewer that this is another important area for further research attention. However, inflammation in the context of diabetes and dementia was not the primary focus of the workshop; therefore, we refer the reader to recent reviews for more in depth attention to this important topic. The following text can be found on p.5, paragraph 1: "Inflammation-related events in the periphery and brain may be another important factor explaining the connection between diabetes and neurocognitive dysfunction (see (Ferreira et al. 2014; De Felice and Lourenco 2015) for recent reviews of this topic)."

Point 6: "Finally, the paper's conclusion with "Some broad research needs" is doubtlessly faithful to the output of the workshop's deliberations, but many of the points outlined in this list come across as rather vague. Without further elaboration, it is not clear what gaps in knowledge some of them would address. One wonders if several could be combined and embellished with a bit more elaboration."

Response: We apologize for being overly vague in this section and have revised this section to provide more clarity.

Competing Interests: No competing interests were disclosed.

The benefits of publishing with F1000Research:

- Your article is published within days, with no editorial bias

- You can publish traditional articles, null/negative results, case reports, data notes and more

- The peer review process is transparent and collaborative

- Your article is indexed in PubMed after passing peer review

- Dedicated customer support at every stage

For pre-submission enquiries, contact research@f1000.com 